\title{
ANALISIS PEMASARAN BUAH PEPAYA DI DESA MATUNGKAS KECAMATAN DIMEMBE KABUPATEN MINAHASA UTARA
}

\author{
Juneke Marisa Sambuaga \\ Rine Kaunang \\ Grace A. J. Rumagit
}

\begin{abstract}
This study aimed to describe marketing papaya fruit on each marketing channel in the village Matungkas Village, North Minahasa District. The research was conducted from February to April 2016. The data used are primary data. The research was done by using purposive sampling with the total number of respondents 45 people. Analysis of the data used is descriptive to portray marketing channels and marketing margin analysis and farmer share. The results showed that there are three patterns of marketing channels, namely: (1) marketing channels first (farmer-traders-retailers) with a marketing margin on the first channel of Rp 8.64 million / trip and farmer share of 40.00 percent. (2) a second marketing channel (farmers, retailers, the district / province) with a marketing margin on retailers in the district amounted to $R p$ 4,200,000 and farmer share of 58.82 percent, while the marketing margin on retailers in the province amounted to Rp 9.6 million / trip and farmer share of 50.00 percent. (3) The third marketing channel (farmer-consumer) with a marketing margin of $R p$ 2,400,000 and farmer share 100 percent. The most efficient marketing channel is channel marketing and channel marketing two third is the channel which is very profitable for farmers.
\end{abstract}

Key words: marketing channel, papaya fruit, Matungkas Village,

\begin{abstract}
ABSTRAK
Penelitian ini bertujuan untuk mendeskripsikan pemasaran buah pepaya pada masing-masing saluran pemasaran di Desa Matungkas. Penelitian dilaksanakan pada bulan Februari sampai April 2016. Data yang digunakan adalah data primer. Penelitian ini dilakukan dengan menggunakan teknik purposive sampling dengan jumlah seluruh responden 45 orang. Analisis data yang digunakan adalah secara deskriptif untuk mengambarkan saluran pemasaran serta analisis marjin pemasaran dan farmer share. Hasil penelitian menunjukan terdapat tiga pola saluran pemasaran yaitu: (1) saluran pemasaran pertama (petani-pedagang pengumpul-pedagang pengecer) dengan marjin pemasaran pada saluran pertama sebesar Rp 8.640.000/trip dan farmer share sebesar 40,00 persen. (2) Saluran pemasaran kedua (petani-pedagang pengecer di kabupaten/propinsi) dengan marjin pemasaran pada pedagang pengecer di kabupaten sebesar Rp 4.200.000 dan farmer share 58,82 persen, sedangkan marjin pemasaran pada pedagang pengecer di propinsi sebesar Rp 9.600.000/trip dan farmer share 50,00 persen. (3) Saluran pemasaran ketiga (petani-konsumen) dengan marjin pemasaran sebesar Rp 2.400 .000 dan farmer share 100 persen. Saluran pemasaran yang paling efisien adalah saluran pemasaran dua dan saluran pemasaran ketiga merupakan saluran yang sangat menguntungkan bagi petani.
\end{abstract}

Kata kunci: saluran pemasaran, buah pepaya, Desa Matungkas, Kabupaten Minahasa Utara

\section{PENDAHULUAN}

Latar Belakang

Sektor pertanian merupakan sektor yang mendapat perhatian cukup besar dari pemerintah karena perannya sebagai sumber penghasil kebutuhan pokok, menyediakan lapangan kerja bagi sebagian besar penduduk, memberikan sumbangan terhadap pendapatan nasional yang tinggi, dan memberikan devisa 
kepada negara. Sektor pertanian terdiri dari berbagai sub sektor yang meliputi sub sektor tanaman pangan, sub sektor hortikultura, sub sektor perikanan, sub sektor peternakan, dan sub sektor kehutanan. Salah satu sub sektor pertanian yang saat ini banyak di geluti masyarakat yaitu sub sektor hortikultura. Salah satu tanaman hortikultura yang di budidayakan di Indonesia adalah buah pepaya.

Pepaya (Carica papaya L) merupakan tanaman yang berasal dari Meksiko bagian selatan dan Amerika. Tanaman ini menyebar ke Benua Afrika dan Asia serta India dari India tanaman ini menyebar ke berbagai negara tropis termasuk Indonesia. Pepaya (Carica papaya L) merupakan tanaman buah berupa herba dari famili Caricaceae dan merupakan komoditi hortikultura yang mempunyai nilai ekonomis yang tinggi. Buah pepaya banyak mengandung vitamin A, B, dan vitamin $C$ yang sangat dibutuhkan oleh tubuh manusia (Rukmana, 2003).

Pada lima tahun terakhir (2010-2014), luas panen dan produksi buah papaya di Indonesia mengalami peningkatan yang cukup pesat yaitu masing-masing 21,87 persen dan 22,33 persen. Dengan total luas panen dari tahun 2010-2014 berjumlah 53.506 ha dengan total produksi 4.290.287 ton. (Direktorat Jendral Hortikultura, 2015). Produktivitas pepaya Indonesia jauh lebih tinggi dibandingkan dari produksi negara tetangga, tetapi sebagian besar produksi itu di serap oleh pasar domestik (Ashari, 2004). Pola usahatani yang masih bersifat tradisonal menyebabkan lemahnya pemasaran buah-buahan di Indonesia. Untuk itu, perlu penaganan yang khusus sejak persiapan hingga di pasarkan.

Tabel 1 menunjukan Produksi pepaya tahun 2010-2011 sebesar 24.431 ton atau 16,06 persen. Dibandingkan tahun 2012 terjadi penurunan produksi sebesar 5.533 ton atau 3,64 persen dan pada tahun 2013 terjadi peningkatan tetapi tidak siknifikan sebesar 5.543 ton atau 3,71 persen . Produksi pepaya pada tahun 20142015 mengalami peningkatan sebesar 44.678 atau 29,47 persen dan 47,342 atau 31,13 persen. Produksi pepaya tertinggi di Sulawesi Utara terjadi pada tahun 2015 yaitu sebesar 47,352 ton atau 31,13 persen. Hal ini tak lepas dari dampak perubahan cuaca/iklim yang ekstrim serta turunnya harga pepaya di pasaran. Maka terjadilah peningkatan dan penurunan produkci,
Tabel 1 Perkembangan Produksi Pepaya di Sulawesi Utara Tahun 2010-2015

\begin{tabular}{ccc}
\hline Tahun & $\begin{array}{c}\text { Produksi } \\
\text { (Ton) }\end{array}$ & $\begin{array}{c}\text { Presentase } \\
(\%)\end{array}$ \\
\hline $\mathbf{2 0 1 0}$ & 24.431 & 16,06 \\
$\mathbf{2 0 1 1}$ & 24.431 & 16,06 \\
$\mathbf{2 0 1 2}$ & 5.543 & 3,64 \\
$\mathbf{2 0 1 3}$ & 5.655 & 3,71 \\
$\mathbf{2 0 1 4}$ & 44.678 & 29,37 \\
$\mathbf{2 0 1 5}$ & 47.352 & 31,13 \\
\hline Sum
\end{tabular}

Sumber: Badan Pusat Statistik 2013-2015

Kecamatan Dimembe merupakan kecamatan terletak di Minahasa Utara dengan luas wilayah mencapai $158,12 \mathrm{~km}^{2}$, terdiri dari 11 desa dengan 82 jaga dan 126 blok sensus (Badan Pusat Statistik, 2015). Kecamtan Dimembe yang terletak di kabupaten Minahasa Utara yang di kenal sebagai sentra buah-buahan salah satunya buah pepaya. Diketahui hasil produksi buah pepaya di Kecamatan Dimembe memiliki produksi tertinggi dibandingkan dengan produksi di kecamatan lainnya.

\begin{tabular}{|c|c|c|c|c|c|c|}
\hline \multicolumn{7}{|c|}{$\begin{array}{l}\text { Tabel 2. Produksi Buah Pepaya Per Kecamatan di } \\
\text { Kabuapaten Minahasa Utara Tahun 2010-2014 }\end{array}$} \\
\hline \multirow{2}{*}{\multicolumn{2}{|c|}{$\begin{array}{l}\text { No } \\
\text { Kecamatan }\end{array}$}} & \multicolumn{5}{|c|}{ Produksi Buah Pepaya Per Tahun (Ton) } \\
\hline & & 2010 & 2011 & 2012 & 2013 & 2014 \\
\hline 1 & Kema & 400 & 175 & 191 & 92 & 47 \\
\hline 2 & Kauditan & 250 & 105 & 100 & 88 & 80 \\
\hline 3 & Airmadidi & 1,400 & 875 & 504 & 185 & 373 \\
\hline 4 & Kalawat & 450 & 152 & 113 & 58 & 2 \\
\hline 5 & Dimembe & 2400 & 1063 & 894 & 735 & 1354 \\
\hline 6 & Talawaan & 710 & 107 & 378 & 8 & 7 \\
\hline 7 & $\begin{array}{l}\text { Likupng } \\
\text { Selatan }\end{array}$ & 28 & 10 & 0 & 0 & 0 \\
\hline 8 & $\begin{array}{l}\text { Likupang } \\
\text { Timur }\end{array}$ & 21 & 29 & 8 & 6 & 3 \\
\hline 9 & $\begin{array}{l}\text { Likupang } \\
\text { Barat }\end{array}$ & 4 & 13 & 29 & 10 & 11 \\
\hline 10 & Wori & 100 & 44 & 8 & 21 & 7 \\
\hline & Sumber: & dan $I$ & t Stc & tik 2 & $3-2$ & \\
\hline
\end{tabular}

Tabel 2 menunjukan bahwa Kecamatan Dimembe memberikan kontribusi pepaya yang sangat besar terhadap Minahasa Utara pada lima tahun berturut-turut dari tahun 2010-2014 yaitu sebesar 2400 ton atau 37,23 persen pada tahun 2010 dan pada tahun 2014 produksi pepaya yaitu sebesar 1.354 ton atau 21,00 persen, meskipun mengalami naik dan turun produksi pepaya di Kabupaten Minahasa Utara, tetap Kecamatan Dimembe menempati peringkat pertama dalam produksi pepaya. Itu karena program penyuluhan budidaya pepaya benar-benar dilaksanakan. 
Salah satu desa di Kecamatan Dimembe, yang menjadi sentra produksi buah pepaya adalah Desa Matungkas, jumlah produksi pepaya yang dihasilkan petani sangat dipengaruhi oleh luas lahan yang dimilikinya, adanya luas lahan yang tidak seragam yang dimiliki setiap petani, akan menyebabkan jumlah produksi yang dihasilkan juga berbeda. Tinggi rendahnya tingkat pengetahuan dan keterampilan yang dimiliki oleh para petani tersebut untuk melakukan kegiatan usahatani pepaya, juga sangat berpengaruh terhadap besarnya jumlah produksi yang dihasilkannya.

Pemasaran merupakan hal yang paling penting dalam menjalankan sebuah usaha pertanian karena pemasaran merupakan tindakan ekonomi yang berpengaruh harga pasar yang rendah, sehingga tingginya produksi tidak mutlak memberikan keuntungan yang tinggi tanpa pemasaran yang baik dan efisien. Secara umum, pemasaran dapat diartikan sebagai segala kegiatan yang dilakukan oleh berbagai perantara dengan berbagai macam cara untuk menyampaikan hasil produksi. (Kotler, 2009)

Kondisi pemasaran komoditas buah pepaya di Desa Matungkas Kecamatan Dimembe dicirikan oleh pola panen yang bersifat musiman dan masih sangat tergantung pada faktor alam, harga yang sangat fluktuatif antar waktu dan sifat produk cepat rusak. Pemasaran masih dilakukan dalam bentuk produk mentah dan belum ada upaya untuk menjadikannya ke dalam bentuk olahan dalam skala besar. karakteristik pepaya yang cepat mengalami kematangan dan kerusakan buah, menyebabkan petani tersebut memerlukan pemasaran yang cepat, karena jika penanganannya tidak cepat dapat menimbulkan biaya penyusutan berupa penurunan harga karena kondisi pepaya yang tidak segar lagi. Jauhnya daerah pemasaran dari sentra produksi memungkinkan timbulnya risiko yaitu: (1) apabila petani tersebut langsung menjual produknya ke konsumen akhir akan memerlukan biaya transportasi yang tinggi, (2) apabila petani menjual hasil produksinya di daerahnya, maka petani tersebut akan menerima harga jual yang terlalu rendah. (Pandapotan, 2008)

Saluran pemasaran adalah rute dan status kepemilikan yang ditempuh oleh suatu produk ketika produk ini mengalir dari penyediaan bahan mentah melalui produsen sampai ke konsumen akhir. Usaha memperlancar arus barang dan jasa dari produsen ke konsumen merupakan faktor yang tidak boleh di abaikan dengan memilih saluran distribusi yang tepat yang akan digunakan dalam rangka menyalurkan barang-barang dan jasa dari produsen ke konsumen. (Hamid, 2006) Meningkatkan pendapatan selalu diperhadapkan pada pertentangan kepentingan. Disatu pihak petani menginginkan harga pepaya yang tinggi, dipihak lain pedagang juga berkepentingan mendapatkan keuntungan yang tinggi dan konsumen juga membeli bila harganya cukup rendah. Diduga, masalah yang ditemukan dalam sistem pemasaran adalah kecil bagian yang diterima petani, atau marjinnya terlalu besar, karena biaya pemasaran yang cukup tinggi dan rendahnya posisi petani disebabkan oleh kebutuhan rumah tangga yang mendesak sementara daya beli relatif rendah. Selain itu, kurang tersedianya sarana transportasi dan informasi mengenai harga pasar menyebabkan petani mengalami kesulitan dalam menetapkan harga jualnya sehingga terjadi perbedaan harga cukup besar antara harga yang diterima petani dan harga yang diterima pengecer dan juga tingginya biaya pemasaran diduga bisa diakibatkan oleh jarak tempuh produsen dan pedagang pengumpul serta konsumen akhir yang jauh. Dalam hal inilah yang terjadi pada pemasaran pepaya di Desa Matungkas.

Efisien atau tidaknya suatu saluran pemasaran, dipengaruhi oleh lembaga-lembaga pemasaran yang terkait di dalamnya. Lembagalembaga pemasaran yang terlibat dalam memasarkan pepaya dari petani hingga konsumen akhir adalah: produsen atau yang disebut sebagai petani, pedagang pengumpul dan pedagang pengecer. Lembaga pemasaran yang berfungsi sebagai penghubung akan membentuk pola saluran pemasaran pepaya, diantara lembaga pemasaran yang ada, posisi petani adalah yang paling rendah (Pandopotan, 2008).

Harga jual di tingkat petani responden pada bulan maret 2016 yang berkisar antara Rp 10.000 per buah dan pedagang penegecer di pasar tradisional Rp18.000-Rp 25.000/buah. Dengan harga yang demikian, maka akan dapat 
mendorong petani untuk meningkatkan produksinya karena kenikan harga bisa berdampak pada meningkatnya pendapatan petani.

Sudiyono (2004) mengungkapkan bahwa sistem pemasaran dikatakan efisien apabila memenuhi dua syarat yaitu mampu menyampaikan hasil-hasil dari petani produsen kepada konsumen dengan biaya semurahmurahnya, dan mampu mengadakan pembagian yang adil bagi seluruh harga yang dibayarkan oleh konsumen terakhir dalam kegiatan produksi. Analisis yang dapat digunakan untuk melihat efisiensi proses pemasaran yaitu mengunakan analisis marjin pemasaran dan farmer share. Namun berapa besar marjin pemasaran pepaya dan berapa besar bagian yang diterima petani perlu diketahui

\section{Pepaya}

Pepaya (Carica papaya L.) merupakan tanaman buah berupa herba dari famili Caricaceae, tanaman yang berasal dari Meksiko bagian selatan dan Amerika kemudian menyebar ke Benua Afrika dan Asia serta India dari India tanaman ini menyebar ke berbagai negara tropis termasuk Indonesia. Tanaman pepaya banyak ditanam baik di daerah tropis maupun sub tropis, di daerah-daerah basah dan kering atau di daerah-daerah dataran dan pegunungan (sampai $1000 \mathrm{~m} \mathrm{dpl}$ ). Buah pepaya merupakan buah bermutu dan bergizi yang tinggi. Berdasarkan taksonominya, tanaman pepaya dapat diklasifikasikan sebagai berikut:

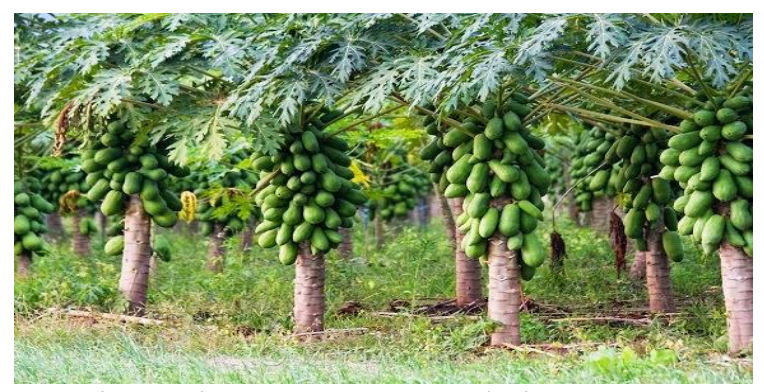

Sumber : http://www.petanihebat.com

$\begin{array}{ll}\text { Kerajaan } & \text { : Plantae } \\ \text { Divisi } & \text { : Spermatophyta } \\ \text { Kelas } & : \text { Angiospermae } \\ \text { Bangsa } & \text { : Caricales } \\ \text { Suku } & : \text { Caricaceae } \\ \text { Marga } & : \text { Carica }\end{array}$

Buah pepaya memiliki banyak varietas, pengelompokan tanaman pepaya ke dalam beberapa varietas didasarkan pada bentuk, ukuran, warna dan tekstur buahnya. Buah pepaya yang di budidayakan petani dan di nikmati konsumen terdiri dari jenis pepaya eksotik dan jenis pepaya lokal. Jenis pepaya eksotik terdiri dari jenis Pepaya California, Pepaya Hawai (Solo, Honolulu, Pontianak, Medan, Taiwan, Jumbo) yang mempunyai ukuran relatif kecil $(0,5-1,5 \mathrm{~kg})$, sedangkan untuk jenis pepaya lokal yang terdiri dari Pepaya Malang, Pepaya Bangkok, Bogor, Pepaya Paris, Pepaya Jinggo, mempunyai ukuran relatif besar $(>2 \mathrm{~kg})$. Pepaya Bangkok memiliki karakteristik antara lain buah buah berbentuk panjang besar dan lancip pada bagian ujung, permukaan buahnya tidak rata dan kulit luarnya relatif tipis, daging buah berwarna jingga kemerahan, keras dan memiliki rasa manis.

\section{Tabel 3. Kandungan Gizi Buah dan Daun Pepaya}

\begin{tabular}{lccc}
\hline \multicolumn{1}{c}{ Zat Gizi } & $\begin{array}{c}\text { Buah } \\
\text { Pepaya } \\
\text { Masak }\end{array}$ & $\begin{array}{c}\text { Buah } \\
\text { Pepaya } \\
\text { Muda }\end{array}$ & $\begin{array}{c}\text { Daun } \\
\text { Pepaya }\end{array}$ \\
\hline Energi (kkal) & 46 & 26 & 79 \\
Protein (g) & 0,5 & 2,1 & 8,0 \\
Lemak (g) & 0 & 0,1 & 2,0 \\
Karbonhidrat & 12,2 & 4,9 & 11,9 \\
(g) & 23 & 50 & 353 \\
Kalsium (mg) & 12 & 16 & 63 \\
Fosfor (mg) & 1,7 & 0,4 & 0,8 \\
Besi (mg) & 365 & 50 & 18,250 \\
Vitamin A (SI) & 0,04 & 0,02 & 140 \\
Vitamin B & & 19 & 140 \\
(mg) & 78 & 92,3 & 75,4 \\
Vitamin C & & & \\
(mg) & Air (g) & 86,7 &
\end{tabular}

Sumber : Anonim, 2016

Kalie (2008), menyatakan bahwa buah pepaya sangat populer karena banyak mengandung vitamin $\mathrm{A}, \mathrm{B}$ dan vitamin $\mathrm{C}$ yang sangat dibutuhkan oleh tubuh manusia, Buah pepaya mengandung enzim papain yang sangat aktif dan memiliki kemampuan mempercepat proses pencernaan protein, karbohidrat dan lemak.bagian tanaman pepaya lainnya juga dapat dimanfaatkan 
seperti Biji, daun, batang, dan akarnya bisa diolah menjadi obat tradisional, pakan ternak dan kosmetik. Pepaya juga dapat diolah menjadi berbagai bentuk makanan dan minuman yang diminati pasar luar negeri seperti olahan puri, pasta pepaya, manisan kering, manisan basah, saus pepaya dan juice pepaya. Bahkan bijinya pun dapat diolah lebih lanjut menjadi minyak dan tepung. Varietas yang beragam dan ketersediaannya sepanjang tahun turut memperkokoh posisi pepaya sebagai buah idola. Adapun susunan kandungan gizi buah dan daun pepaya, dapat di lihat pada Tabel 3 .

Tabel 3 menunjukan bahwa kandungan gizi tertinggi yang terdapat dalam buah pepaya adalah vitamin A, yaitu 365 SI pada buah masak, 50 SI pada buah mentah, dan 18.250 SI pada daun. Hal ini dapat menunjukkan bahwa buah pepaya sangat penting dikonsumsi oleh manusia.

\section{Pemasaran}

Kegiatan pemasaran sering diartikan sebagai kegiatan dalam memasarakan suatu produk yang diperjual belikan oleh perusahaan dan ditunjukan kepada konsumen, namun jika dilihat makna sebenarnya pemasaran bukan hanya sekedar menjual produk saja, akan tetapi pemasaran juga memiliki aktivitas penting dalam menganalisis dan mengevaluasi segala kebutuhan dan keinginan para konsumen.

Pemasaran merupakan proses dimana perusahaan menentukan produk atau jasa yang mungkin menarik untuk pelanggan, dan strategi yang digunakan adalah penjualan (Usman, 2006). Laksana (2008), pemasaran merupakan proses sosial yang didalamnya individu dan kelompok mendapatkan apa yang dibutuhkan dan diinginkan dengan menciptakan, menawarkan dan mempertukarkan produk yang bernilai dengan pihak lain.

Menurut Swastha dan Handoko (2010), mendefinisikan pemasaran itu adalah sistem keseluruhan dari usaha yang ditujukan untuk merencanakan, menentukan harga, mem-promosikan dan mendistribusikan barang dan jasa yang dapat memuaskan kebutuhan pembeli.

Ditinjau dari aspek ekonomi kegiatan pemasaran pertanian dikatakan sebagai kegiatan produktif sebab pemasaran pertanian dapat meningkatkan guna waktu (time utility), guna tempat (place utility), guna bentuk (formutility) dan guna pemilikan (possesion utility). Ko-moditi pertanian yang sudah mengalami pe-ningkatan guna waktu, guna tempat dan guna bentuk baru dapat memenuhi kebutuhan konsumen, apabila sudah terjadi pemindahan hak milik dari produsen atau lembaga pe-masaran kepada konsumen (Sudiyono, 2004).

Kotler (2009) menyatakan pemasaran adalah proses sosial dan managerial yang membuat individu dan kelompok memperoleh apa yang mereka butuhkan dan inginkan lewat penciptaan dan pertukaran timbal balik produk, dengan orang lain.

\section{Saluran Pemasaran}

Kotler (2009), saluran pemasaran merupakan organisasi-organisasi yang saling tergantung yang tercakup dalam proses membuat produk atau jasa menjadi tersedia untuk digunakan atau dikomsumsi. Nitisemito (2000), saluran distribusi adalah lembagalembaga distributor atau lembaga-lembaga penyalur yang mempunyai kegiatan untuk menyalurkan barang-barang atau jasa-jasa dari produsen ke konsumen. Boyd et all (2000) dalam Abednego (2008) menyatakan bahwa, saluran pemasaran adalah himpunan organisasi yang saling bergantung yang terlibat dalam proses untuk membuat produk atau jasa yang siap untuk dikomsumsi atau digunakan oleh konsumen atau penguna industri. Saluran pemasaran terdapat empat desain saluran yang di gunakan dalam mendistribusikan produk, yaitu: 


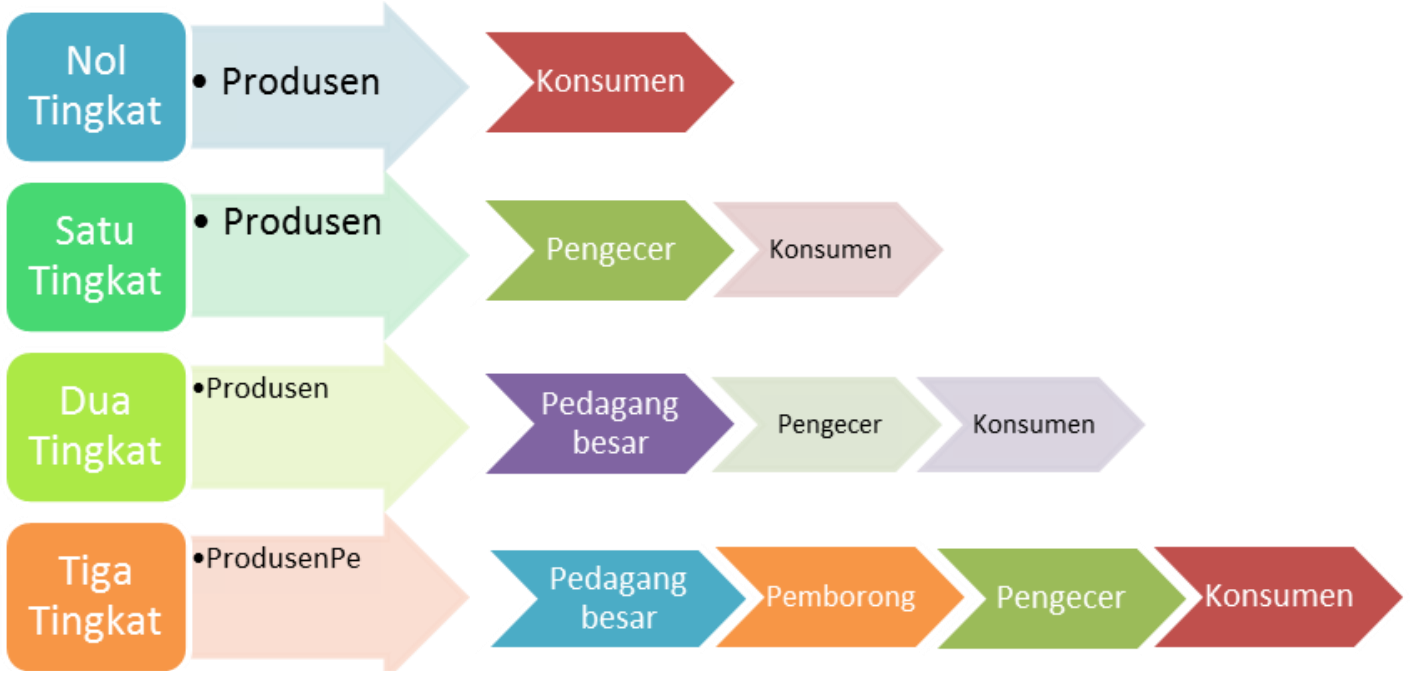

Sumber: Boyd eatall dalam Abednego Saluran Pemasaran komsumsi

1) Saluran nol-tingkat atau saluran pemasaran langsung (Zero levels channel or direct marketing channel), bentuk saluran ini adalah bentuk saluran yang paling pendek dan sederhana sebab tanpa mengunakan perantara. Produsen dapat menjual barang yang dihasilkan melalui pos atau langsung mendatangi rumah konsumen.

2) Saluran satu-tingkat (one level), penjulan melalui satu perantara. Didalam saluran pemasaran barang komsumsi, perantara ini merupakan pedagang besar atau grosir, di sini pedagang besar langsung melakukan

3) pembelian pada produsen. Adapula beberapa produsen yang mendirikan toko pengecer sehingga dapat secara langsung melayani konsumen.

4) Saluran dua-tingkat (two level), penjualan yang mempunyai dua perentara yaitu pedangan besar atau grosir dan pengecer, disini produsen hanya melayani pembelian dalam jumlah besar saja tidak menjual kepada pengecer. Pembelian oleh pengecer dilayani pedagang besar dan pembelian oleh konsumen dilayani oleh pengecer saja.

5) Saluran tiga-tingkat (tree level),penjualan yang mempunyai tiga perantara, yaitu pedagang besar (grosir) sebagai pemborong dan pengecer, disini produsen memilih pedagang besar sebagai penyalurnya, dia menjalankan kegiatan perdagangan besar dalam saluran distribusi yang ada. Sasaran penjualannya di tunjukan kepada pengecer besar.

Jika di gambarkan keempat saluran pemasaran komsumsi dapat dilihat pada gambar

Widiastuti (2013), menyatakan bahwa, panjang pendeknya saluran pemasaran yang dilalui suatu produk pertanian tergantung dari beberapa faktor, antara lain:

1. Jarak antara produsen dan konsumen, semakin jauh jarak makin panjang saluran pemasaran yang di tempuh oleh produk

2. Cepat tidaknya produk rusak, semakin produk cepat rusak harus cepat sampai ke konsumen, sehingga menghendaki saluran yang pendek dan cepat

3. Skala produksi, jika produksinya skala kecil maka tidak menguntungkan bila produsen menjualnya langsung ke pasar, sehingga saluran pemasaran yang di lalui cendrung panjang.

4. Posisi keuangan pengusaha, produsen yang posisi keuangannya kuat, cenderung untuk memperpendek saluran pemasaran

\section{Lembaga dan Fungsi-Fungsi Pemasaran}

Moehar (2001), menjelaskan bahwa lembaga pemasaran adalah badan-badan yang menyelenggarakan kegiatan atau fungsi 
pemasaran dimana barang bergerak dari produsen sampai ke konsumen. Lembaga pemasaran ini bisa termasuk golongan produsen, pedagang perantara, dan lembaga pemberi jasa. Tugas lembaga pemasaran adalah menjalankan fungsi-fungsi pemasaran serta memenuhi keinginan konsumen semaksimal mungkin. Konsumen memberikan balas jasa kepada lembaga pemasaran berupa marjin pemasaran.

Sudiyono (2004), dalam pemasaran barang atau jasa terlibat beberapa badan mulai dari produsen, lembaga-lembaga perantara dan konsumen. Karena jarak antara produsen yang menghasilkan barang atau jasa sering berjauhan dengan konsumen, maka fungsi badan perantara sangat diharapkan kehadirannya untuk menggerakkan barang-barang dan jasa-jasa tersebut dari titik produksi ke titik konsumsi. Lembaga pemasaran merupakan suatu lembaga dalam bentuk perorangan, perserikatan atau perseroan yang akan melakukan fungsi-fungsi pemasaran yang berusaha untuk memperlancar arus/gerak barang dari produsen sampai tingkat konsumen melalui berbagai kegiatan/aktifitas.

Lembaga-lembaga tersebut juga berfungsi sebagai sumber informasi mengenai suatu barang dan jasa. Ada tiga kelompok yang secara langsung terlibat dalam penyaluran barang/jasa mulai dari tingkat produsen sampai tingkat konsumen, yaitu: (1) pihak produsen, (2) lembaga-lembaga perantara dan (3) pihak konsumen akhir. Pihak produsen adalah pihak yang memproduksi barang dan jasa yang dipasarkan, seperti: petani sayur, petani buah, pabrik rokok, dan lain-lain. Pihak lembaga perantara adalah yang memberikan pelayanan dalam hubungannya dengan pembelian dan penjualan barang/jasa dari produsen ke konsumen, yaitu pedagang besar, pedagang pengumpul dan pedagang pengecer, sedangkan konsumen akhir adalah pihak yang langsung menggunakan barang/jasa yang dipasarkan, konsumen akhir ini dapat terdiri dari rumah tangga dan perusahaan-perusahaan.

Moehar (2001), mengatakan fungsi pemasaran sebagai kegiatan-kegiatan atau tindakan-tindakan yang dapat memperlancar proses penyampaian barang atau jasa. Fungsifungsi pemasaran yang dilaksanakan oleh lembaga lembaga pemasaran pada prinsipnya terdapat tiga tipe, yaitu fungsi pertukaran, fungsi fisik dan fungsi penyediaan fasilitas. Fungsi-fungsi pemasaran dapat dikelompokkan atas tiga fungsi yaitu:

\section{Fungsi Pertukaran}

Kegiatan yang memperlancar perpindahan hak milik barang dan jasa yang dipasarkan. Fungsi pertukaran terdiri dari fungsi penjualan dan fungsi pembelian. Dalam malakukan fungsi penjualan, maka produsen atau lembaga pemasaran yang berada pada rantai pemasaran sebelumnnya harus memperhatikan kualitas, kuantitas, bentuk dan waktu serta harga yang diinginkan konsumen ataupun lembaga pemasaran yang ada pada rantai pemasaran berikutnya.

Sedangkan fungsi pembelian diperlukan untuk memiliki komoditi-komoditi pertanian yang akan dikonsumsi ataupun digunakan dalam proses produksi berikutnya.

\section{Fungsi Fisik}

Kegiatan-kegiatan yang secara langsung diperlukan terhadap komoditi pertanian, sehingga komoditi-komoditi pertanian tersebut mengalami tambahan guna tempat dan guna waktu. Fungsi fisik meliputi pengangkutan dan penyimpanan. Fungsi pengangkutan atau transportasi adalah memindahkan produkproduk pertanian dari daerah surplus, dimana kegunaan produk pertanian rendah kedaerah minus atau kegunaan tinggi atau dari daerah produsen ke daerah konsumen. Fungsi penyimpanan diperlukan karena produksi komoditi pertanian bersifat musiman, sedangkan pola konsumsi bersifat relatif tetap.

\section{Fungsi Fasilitas}

Semua tindakan yang bertujuan untuk memperlancar kegiatan pertukaran yang terjadi antara produsen dan konsumen. Fungsi penyediaan fasilitas merupakan usaha-usaha perbaikan sistem pemasaran untuk meningkatkan efisiensi operasional dan efisiensi penetapan harga. Fungsi fasilitas terdiri dari, fungsi penanggungan resiko, dan fungsi informasi pasar.

Selama pergerakan komoditi dari pusat produsen ke konsumen menghadapi kerusakan, kehilangan dan resiko lain. Resiko ini pada prinsipnya diklasifikasikan menjadi dua yaitu resiko fisik, seperti penyusutan berat 
dan volume komoditi pertanian, kehilangan serta kebakaran dan resiko ekonomi, seperti fluktuasi harga. Informasi pasar sangat penting mempertemukan potensial penawaran dan permintaan. Informasi pasar selain mencantumkan harga komoditi per satuan, sebaiknya juga menginformasikan mengenai persediaan, kualitas komoditi dingkat pasar pada tempat dan waktu tertentu.

\section{Biaya Pemasaran}

Secara umum biaya merupakan pengorbanan yang dikeluarkan oleh produsen dalam mengelola usaha taninya untuk mendapatkan hasil yang maksimal. Biaya merupakan pengorbanan yang diukur untuk suatu alat tukar berupa uang yang dilakukan untuk mencapai tujuan tertentu dalam usahataninya. Biaya pemasaran komoditas pertanian meliputi biaya transportasi/biaya angkut, biaya pungutan retribusi, biaya penyusutan dan lain-lain, besarnya biaya pemasaran berbeda satu sama lain. Suratiyah (2006).

Besar-kecilnya biaya pemasaran antar lembaga pemasaran berbeda-beda. Hal ini disebabkan oleh :

1. Macam komoditi, sifat dari komoditi pertanian, adalah mudah rusak (perishable), sehingga biaya yang dikeluarkan untuk melaksanakan fungsi pemasaran lebih besar.

2. Lokasi pengusahaan, lokasi pengusahaan komoditi pertanian yang terpencar akan mengundang tambahan biaya pengangkutan. Hal ini akan berakibat pada bertambah besarnya biaya pemasaran.

3. Macam dan Peranan lembaga pemasaran, biaya pemasaran akan bertambah besar apabila terlalu banyak lembaga pemasaran yang terlibat dalam proses pemasaran (Suratiyah, 2006).

\section{Efisiensi Pemasaran}

Sudiyono (2004) mangungkapkan bahwa sistem pemasaran dikatakan efisien apabila memenuhi dua syarat yaitu mampu menyampaikan hasil-hasil dari petani produsen kepada konsumen dengan biaya semurahmurahnya, dan mampu mengadakan pembagian yang adil bagi seluruh harga yang dibayarkan oleh konsumen terakhir dalam kegiatan produksi. Analisis yang dapat digunakan untuk menentukan efisiensi pada proses pemasaran suatu produk yaitu analisis marjin pemasaran dan farmer share.

\section{Marjin Pemasaran}

Marjin pemasaran adalah selisih harga konsumen dengan harga produsen atau merupakan jumlah biaya pemasaran yang dikeluarkan dengan keuntungan yang diharapkan oleh masing-masing lembaga pemasaran yang terlibat dalam aktivitas pemasaran (Roziah, 2005).

Menurut Kotler dan Keller (2007), marjin pemasaran adalah perbedaan harga yang dibayar konsumen akhir untuk suatu produk dan harga yang diterima petani produsen untuk produk yang sama (rupiah per buah), marjin pemasaran termasuk semua ongkos yang menggerakkan produk tersebut mulai dipintu gerbang petani sampai ketangan konsumen akhir. Menurut Sudiyono (2004) marjin pemasaran dapat dihitung dengan menggunkan rumus sebagai berikut:

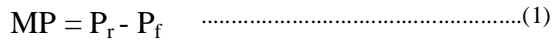

dimana :

$$
\begin{aligned}
\operatorname{Mp} & =\text { Marjin pemasaran } \\
\operatorname{Pr} & =\text { Harga ditingkat konsumen } \\
\operatorname{Pf} & =\text { Harga ditingkat produsen/petani }
\end{aligned}
$$

Menurut Tomek dan Robinson dalam Simon (2001), Untuk mengetehaui besarnya profit marjin setiap lembaga pemasaran digunakan perhitungan sebagai berikut: $\mathrm{P}=\mathrm{M}-\mathrm{C}$

dimana:

$$
\begin{aligned}
& \mathrm{P} \quad=\text { Keuntungan Marjin } \\
& \mathrm{M} \quad=\text { Harga di tingkat pedagang pengumpul } \\
& \text { atau pedagang pengecer } \\
& \mathrm{C} \quad=\text { Biaya Pemasaran }
\end{aligned}
$$

Menurut Tomek dan Robinson dalam Simon (2001) Untuk menghitung presentase marjin pemasaran dapat mengunkan rumus sebagai berikut:

$$
\mathrm{P}=\frac{M}{H K} \mathrm{X} 100 \%
$$

dimana:

$$
\begin{array}{ll}
\mathrm{P} & =\text { Presentase Marjin } \\
\mathrm{M} & =\text { Marjin Pemasaran } \\
\mathrm{HK} & =\text { Harga Konsumen }
\end{array}
$$




\section{Farmer share}

Margin pemasaran bukanlah satu-satunya indikator yang menentukan efisiensi pemasaran suatu komoditas. Salah satu indikator lain adalah dengan membandingkan harga yang dibayarkan oleh konsumen akhir atau biasa disebut dengan farmer share, dan dinyatakan dalam persentase. Farmer share memiliki hubungan negatif dengan margin pemasaran, sehingga semakin tinggi margin pemasaran maka bagian yang akan diperoleh petani semakin rendah.

Farmer share dapat dihitung berdasarkan persentase jumlah harga yang di terima oleh petani/produsen dibagi dengan harga yang terbentuk pada konsumen akhir. Dimana makin besar marjin pemasaran maka bagian yang diterima petani makin kecil bagian yang diterima oleh petani dan sebaliknya (Tomek dan Robinson dalam Simon, 2001). Secara sistematis Farmer share dapat di rumuskan sebagai berikut:

$$
\begin{aligned}
& \text { Fs }=\frac{P \mathrm{P}}{\boldsymbol{P r}} \times \mathbf{X} 100 \% \\
& \text { dimana: }
\end{aligned}
$$

$$
\begin{array}{ll}
\text { Fs } & : \text { Farmer Share } \\
\text { Pf } & \text { : Harga di tingkat petani } \\
\text { Pr } & \text { : Harga di tingkat konsumen }
\end{array}
$$

Untuk melihat efisiensi harga yang terjadi dapat dihitung dengan menggunakan bagian harga konsumen yang di terima petani. Kriteria yang digunakan untuk mengetahui bahwa pemasaran buah pepaya dianggap efisien adalah tiap-tiap saluran pemasaran mempunyai nilai persentase margin pemasaran yang rendah dan mempunyai nilai persentase bagian yang diterima petani (Farmer Share) tinggi.

\section{Penelitian Sebelumnya}

Penelitian dari Pandopotan, A (2008) dengan judul Analisis Pendapatan Usahatani dan Saluran Pemasaran Pepaya California di Desa Cimande dan Lemahduhur Kecamtan

\begin{tabular}{|c|c|}
\hline Petani & Pabrik \\
\hline
\end{tabular}
Curigan Terdapat dua pola saluran

1. Pola Pemasaran $1(90 \%)$

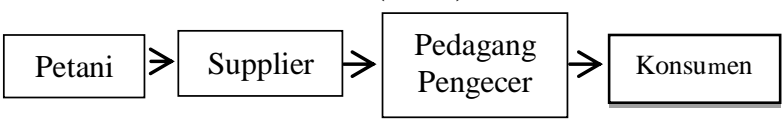

2. Pola Pemasaran II (10 \%)
Margin pemasaraan terbesar diperoleh petani pada pola saluran II yaitu 79,26 persen, sedangkan petani pada pola saluran I memperoleh marjin pemasaran sebesar 74,67 persen. Biaya pemasaran terbesar pada pola saluran I terjadi pada pedagang pengecer, yang mana pedagang tersebut harus membayar biaya pelabelan (Rp 250 per $\mathrm{kg}$ ), biaya penyimpanan ( Rp 274 per $\mathrm{kg}$ ) dan biaya pengemasan ( Rp 100 per $\mathrm{kg}$ ). Sedangkan supplier hanya mengeluarkan biaya transportasi Rp 175 per $\mathrm{kg}$, biaya tenaga kerja $\mathrm{Rp} 25$ per $\mathrm{kg}$ dan biaya pengemasan (Rp 215 per $\mathrm{kg}$ ) untuk melakukan pemasarannya. Total biaya pemasaran yang dikeluarkan dalam pola saluran I adalah Rp 1.039 per $\mathrm{kg}(13,85$ persen$)$ dari harga jual pedagang pengecer.

Pada pola saluran pemasaran II, petani terlibat dalam memasarkan produknya. Sehingga petani tersebut harus mengeluarkan biaya pemasaran sebesar $\mathrm{Rp} 179,17$ per $\mathrm{kg}$ yang terdiri dari biaya transportasi (Rp 166, 67 per $\mathrm{kg}$ ) dan biaya pengemasan $(\mathrm{Rp} 12,5$ per $\mathrm{kg}$ ). Total biaya pemasaran pada pola saluran II adalah $\mathrm{Rp} 179,17$ per $\mathrm{kg}$ (8,14 persen) yang berasal dari petani tersebut. Dari penjelasan tersebut maka dapat dikatakan bahwa biaya pemasaran adalah seluruh biaya yang dikeluarkan oleh lembaga pemasaran pada setiap saluran pemasaran untuk memasarkan/ menyalurkan produk dari produsen ke konsumen. Berdasarkan keuntungan yang diperoleh, maka petani pada pola saluran I memperoleh total keuntungan sebesar Rp 4.561 per $\mathrm{kg}(60,81$ persen) dari harga jual pedagang pengecer, sedangkan petani pada pola saluran II memperoleh. Keuntungan sebesar Rp 1.564,53 per kg $(71,11$ persen) dari harga beli konsumen akhir. Hal ini dapat disebabkan karena pada pola saluran II tersebut, petani merupakan satusatunya lembaga pemasaran yang terlibat dalam menyalurkan pepaya ke konsumen akhir

Kesimpulkan bahwa sistem saluran pemasaran yang paling efisien terdapat pada pola saluran pemasaran II karena petani tersebut memperoleh farmer's share (bagian yang diterima petani) sebesar 100 persen, sedangkan pada pola saluran I petani hanya memperoleh farmer's share sebesar 25,33 persen.

Penelitian dari Sobirin, 2009, dengan judul Efisiensi Pemasaran Pepaya (Carica pepaya l.) Tujuan penelitian adalah: (1) mengetahui 
besarnya marjin pemasaran, (2) mengetahui farmer's share, bagian biaya pemasaran dan keuntungan pedagang, (3)mengetahui besarnya profit marjin pada setiap saluran pemasaran, (4) mengetahui efisiensi pemasaran pepaya di Kecamatan Sumbang, (5) mengetahui pengaruh perubahan harga di tingkat pengecer terhadap perubahan harga di tingkat petani. Saluran pemasaran pepaya di Kecamatan Sumbanga terdapat tiga macam, yaitu:

a) Saluran I (21,27\%)

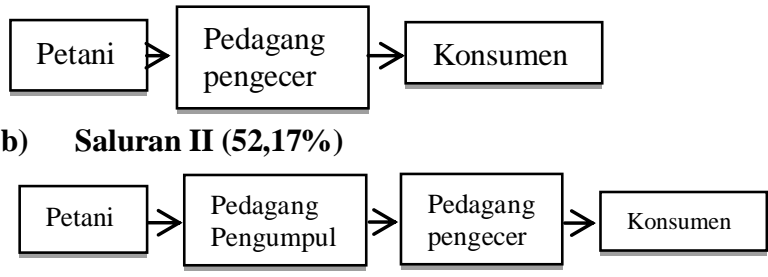

c)Saluran III (26.09\%)

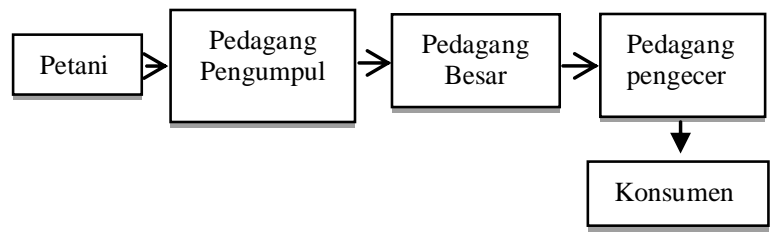

Persentase jumlah petani di saluran I sebanyak 21,74 persen dari total petani responden, persentase jumlah petanidi saluran II sebanyak 52,17 persen dari total petani responden, dan persentase jumlah petani di saluran III sebanyak 26,09 persen dari total petani responden. Saluran yang banyak digunakan untuk petani adalah saluran II sebanyak 52,17 persen persen dari total petani responden

Hasil penelitian menunjukkan bahwa : (1) besarnya marjin pemasaran pepaya di kecamatan Sumbang untuk saluran I adalah Rp759,00 per kg, saluran II adalah Rp1.177,50 per kg dan saluran III adalah 1.66,67 per kg, (2) besarnya farmer's share untuk saluran I adalah 58,42 persen, saluran II adalah 51,74 persen dan saluran III adalah 49,33 persen. Persentase biaya untuk saluran I adalah 40,97 persen, saluran II adalah 32,66 persen dan saluran III adalah 42,4 persen.Persentase keuntungan untuk saluran I adalah 59,03 persen, saluran II adalah 67,34 persen dan saluran III adalah 57,76 persen, (3) profit marjin yang diterima pedagang di saluran I adalah 22,61 persen, saluran II adalah 32,86 persen dan saluran III adalah 29,69 persen (4) pemasaran pepaya di Kecamatan Sumbang belum efisien (5) elastisitas transmisi harga yang terjadi di pasar produsen dan konsumen sebesar 0,95. Hal tersebut menunjukkan bahwa perubahan harga ditingkat pengecer berpengaruh terhadap perubahan harga di tingkat petani.

Berdasarkan penelitian sebelumnya diketahui bahwa terdapat beberapa kesamaan, sehingga menjadi pertimbangan peneliti dalam menyusun rencana penelitian, adapun kesamaankesamaan tersebut adalah sebagai berikut:

1) Adanya kesamaan topik dalam bidang kajian penelitian, yaitu mengenai pemasaran pepaya dalam penelitian Pandopotan (2008) dan Sobirin (2009).

2) Berdasarkan penelitian di atas dapat disimpulkan bahwa semakin pendek saluran pemasaran suatu produk dengan marjin pemasaran rendah serta farmer's share yang tinggi, maka pemasaran akan semakin efisien serta memberikan keuntungan kepada produsen.

\section{Kerangka Pemikiran}

Pepaya merupakan buah yang segar untuk di cicipi oleh lidah manusia, pepaya relatif disukai semua lapisan masyarakat karena cita rasanya yang enak, kaya vitamin A, B dan C yang sangat dibutuhkan oleh tubuh manusia, selain kaya akan vitamin, pepaya juga mampu menjangkau semua lapisan masyarakat karna harganya murah. Semakin meningkatnya kesadaran masyarakat akan pentingnya gizi buah tersebut, dapat meningkatkan permintaan terhadap pepaya sehingga jumlah produksi pepaya juga harus ditingkatkan. Salah satu cara untuk meningkatkan produksi pepaya adalah dengan teknik budidaya yang tepat.

Sistem pemasaran yang efisien sangat mempengaruhi tingkat pendapatan petani. Agar sistem pemasaran dapat seefisien mungkin dilakukan, maka petani harus memilih saluran pemasaran yang tepat sehingga mampu menekan biaya pemasaran. Adanya perbedaan dari kegiatan dari setiap lembaga pemasaran dapat menyebabkan adanya perbedaan antara harga jual dari lembaga yang satu dengan yang lain sampai ke tingkat konsumen akhir. Jika semakin banyak lembaga pemasaran yang terlibat dalam penyaluran komoditas maka akan semakin besar perbedaan harga komoditas tersebut ditingkat produsen dibandingkan dengan harga yang akan dibayar oleh konsumen. Pemasaran yang efisien dapat dilihat dari analisis saluran pemasaran dan efisiensi pemasaran yang meliputi analisis. Analisis marjin pemasaran, biaya, keuntungan. dan analisis farmer share, Karangka pemikiran penelitian. 


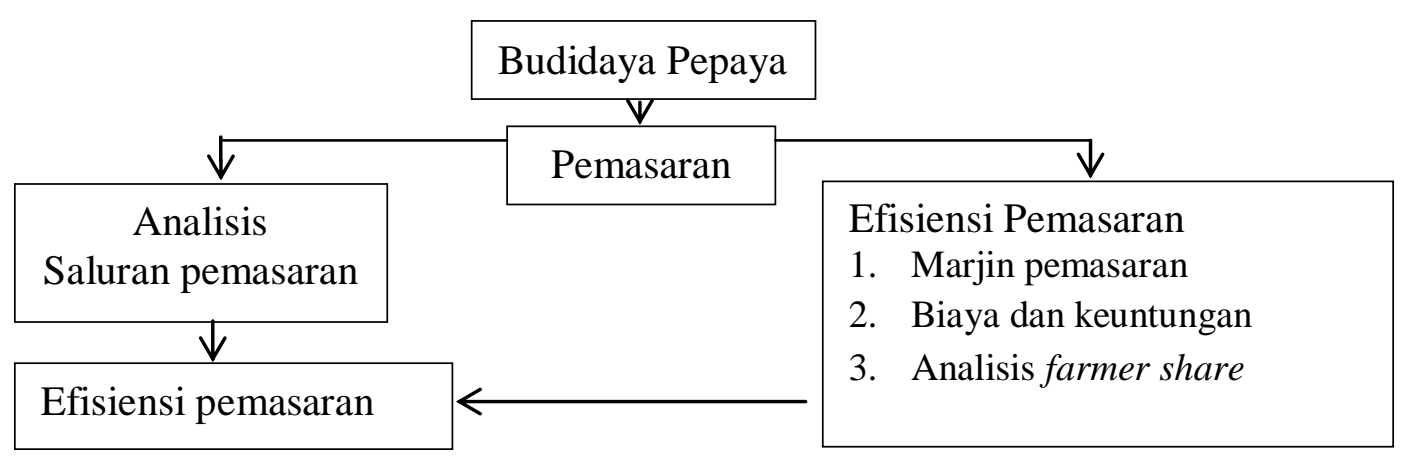

Gambar 2. Kerangka Pemikiran Penelitian

\section{Rumusan Masalah}

Berdasarkan latar belakang yang telah di kemukakan maka menjadi permasalahan peneliti adalah Bagaimana pemasaran buah pepaya pada masing-masing saluran pemasaran di Desa Matungkas Kecamatan Dimembe?

\section{Tujuan Penelitian}

Tujuan dari penelitian ini adalah untuk mendeskripsikan pemasaran buah pepaya pada masing-masing saluran pemasaran di Desa Matungkas.

\section{Manfaat Penelitian}

Manfaat dari penelitian ini adalah sebagai masukan bagi petani pepaya di daerah penelitian untuk memperbaiki kinerja dari masing-masing saluran agar lebih efisien dan memperbaiki fungsi-fungsi pemasaran.

\section{METODOLOGI PENELITIAN}

\section{Tempat dan Waktu Penelitian}

Lokasi yang menjadi sampel penelitian yaitu Desa Matungkas Kecamatan Dimembe Kabupaten Minahasa Utara. Dengan pertimbangan bahwa Desa Matungkas merupakan daerah penghasil buah pepaya yang sebagian besar penduduknya bermata pencaharian sebagai petani yang membudidayakan buah pepaya. Waktu penelitian di mulai pada bulan Februari sampai April 2016, mulai dari persiapan, pengumpulan data, pengolahan data sampai dengan pembuatan laporan.

\section{Metode Pengumpulan Data}

Metode yang digunakan dalam penelitian ini adalah metode deskriptif yaitu mengunakan data primer dan sekunder, untuk mendapatkan data primer digunakan dengan cara wawancara langsung yang di bantu daftar pertanyaan yang telah di siapkan kepada petani dan lembaga pemasaran sebagai responden. Sedangkan data sekunder di peroleh dari sumber-sumber yang berhubungan dengan objek penelitian, yaitu Kantor Desa, Badan Pusat Statistik Minahasa Utara dan Badan Pusat Statistik di Sulawesi Utara.

\section{Metode Pengambilan Sampel}

Metode pengambilan sampel pada petani dilakukan dengan mengunakan metode purposive sampling yaitu petani sampel adalah petani secara sengaja bertemu dengan peneliti. Jumlah petani yang menjadi responden sebanyak 24 orang petani pepaya, Jumlah pedagang pengumpul yang menjadi responden sebanyak 6 orang dan pedagang pengecer berjumlah 13 orang. Maka total sampel berjumlah 45 orang.

\section{Konsep Pengukuran Variabel}

Variable dan satuan ukuran dalam penelitian yaitu:

1. Saluran pemasaran pepaya adalah rantai pemasaran pepaya dari produsen sampai ke konsumen akhir.

2. Harga ditingkat petani adalah penerimaan harga petani pepaya dari lembaga pemasaran, dinyatakan dalam satuan Rp/buah 
3. Harga ditingkat pedagang pengumpul adalah harga yang diterima dari pedagang pengumupul dari hasil penjualan kepada pedagang pengecer, dinyatakan dalam satuan Rp/buah

4. Harga ditingkat pedagang pengecer adalah harga yang diterima dari pedagang pengecer dari hasil penjualan kepada konsumen, dinyatakan dalam satuan $\mathrm{Rp}$ / buah

5. Biaya pemasaran adalah semua biaya yang di keluarkan oleh lembaga pemasaran dalam memasarkan pepaya, dinyatakan dalam satuan $\mathrm{Rp} / \mathrm{buah}$

6. Keuntungan adalah marjin di kurangi biaya pemasaran di nyatakan dalam satuan $\mathrm{Rp} / \mathrm{buah}$

7. Margin pemasaran pepaya adalah perbedaan harga yang dibayar oleh konsumen akhir dengan harga yang diterima produsen, di nyatakan dalam satuan $\mathrm{Rp} /$ buah

8. Farmer share adalah perbandingan antara harga yang diterima produsen

dengan harga yang diterima konsumen yang dinyatakan dalam persen (\%).

\section{Metode Analisis Data}

Metode analisis data yang akan digunakan dalam penelitian di Desa Matungkas Kecamatan Dimembe adalah:

1. Untuk mengetahaui saluran pemasaran dan lembaga pemasaran pepaya yang ada di Desa Matungkas, Kecamatan Dimembe, mengunakan metode analisis deskriptif.

2. Untuk mengetahui marjin pemasaran dan biaya pemasaran di tingkat lembaga dalam saluran pemasaran digunakan analisis marjin pemasaran yaitu dengan menghitung besarnya biaya, keuntungan, dan marjin pemasaran pada tiap lembaga perantara pada berbagai saluran pemasaran

a. Marjin Pemasaran adalah selisih harga tingkat konsumen akhir dengan harga produsen. Menurut Tomek dan Robinson dalam Simon (2001) marjin pemasaran dihitung dengan mengunakan rumus sebagai berikut:

$$
\mathbf{M}=\mathbf{P}_{\mathbf{r}}-\mathbf{P}_{\mathbf{f}}
$$

dimana:

$$
\begin{aligned}
& \mathrm{M}: \text { Marjin pemasaran Rp/buah) } \\
& \operatorname{Pr}: \text { Harga ditingkat konsuen (Rp/buah) } \\
& \text { Pf : Harga ditingkat produsen (Rp/ buah) }
\end{aligned}
$$

b. Biaya Pemasaran adalah biaya yang di keluarkan untuk memasarkan suatu komoditi dari produsen ke konsumen. Menurut Pearce dan Robinson (2011), Biaya pemasaran dapat di rumuskan sebagai berikut:

$$
\begin{aligned}
& B p=B p 1+B p 2+B p 3 \ldots . . .+B p n \\
& \text { dimana: } \\
& \text { Bp } \quad \text { : Biaya pemasaran pepaya } \\
& \text { Bp1,2,3..n : Biaya pemasaran tiap } \\
& \text { lembaga pemasaran pepaya } \\
& \text { (Rp/ buah) }
\end{aligned}
$$

c. Keuntungan Pemasaran

Menurut Tomek dan Robinson dalam Simon (2001), Untuk mengetehaui besarnya profit marjin setiap lembaga pemasaran digunakan perhitungan sebagai berikut:

$$
\begin{aligned}
& \mathbf{P}=\mathbf{M}-\mathbf{C} \\
& \text { dimana: } \\
& \mathrm{P}=\text { Keuntungan Marjin }(\mathrm{Rp} / \mathrm{buah}) \\
& \mathrm{M} \quad=\text { Harga di tingkat pedagang } \\
& \text { ( } \mathrm{Rp} / \text { buah) } \\
& \text { C = Biaya Pemasaran (Rp/buah) }
\end{aligned}
$$

3. Farmer share, dapat dihitung berdasarkan persentase jumlah harga yang di terima oleh petani/produsen dibagi dengan harga yang terbentuk pada konsumen akhir. Secara sisitematis dapat di rumuskan sebagai berikut:

$$
\mathrm{Fs}=\frac{P \mathrm{f}}{P r} \times 100 \text {........ }
$$

dimana :

$\begin{array}{ll}\text { Fs } & : \text { Farmer Shere } \\ \text { Pf } & : \text { Harga di tingkat petani } \\ \operatorname{Pr} & : \text { Harga di tingkat konsumen }\end{array}$

\section{HASIL DAN PEMBAHASAN}

\section{Deskripsi Wilayah Penelitian}

\section{a) Letak dan Luas Wilayah}

Desa Matungkas berada pada ketinggian $200 \mathrm{mdpl}$ (meter diatas permukaan laut), memiliki luas 2.080 ha dan terbagi atas 11 jaga. Batas 
wilayah administratif Desa Matungkas sebagai berikut:

\section{Sebelah Utara \\ : Desa Laikit Kecamatan Dimembe \\ 2. Sebelah Timur \\ : Desa Airmadidi Kecamatan Airmadidi \\ 3. Sebelah Selatan \\ : Desa Sukur Kecamatan Airmadidi \\ 4. Sebelah Barat \\ : Desa Paniki \\ Kecamatan Mapanget}

Jarak kantor desa dengan ibukota kecamatan $4 \mathrm{~km}$, dan jarak kantor desa dengan ibukota kabupaten $3 \mathrm{~km}$.

\section{b) Penduduk Desa Matungkas}

Jumlah penduduk Desa Matungkas adalah 4.042 jiwa. Jumlah laki-laki 2.047 jiwa dan jumlah perempuan 1995 jiwa.

\section{c) Mata Pencaharian}

Mata pencaharian penduduk Desa Matungkas umumnya bersumber dari hasil-hasil pertanian terutama budidaya buah pepaya. Selain berprofesi sebagai petani, penduduk yang ada di Desa Matungkas juga ada yang bermata pencarian sebagai tukang ojek, pegawai sipil, dan wiraswasta.

\section{Karakteristik Responden}

Identitas responden merupakan gambaran secara umum dalam menjalankan suatu kegiatan usahatani baik yang bersifat subsisten maupun usahatani yang sudah komersil, dalam menjalankan usahatani dipengaruhi oleh beberapa faktor, yaitu: umur dari petani itu sendiri, tingkat pendidikan dan luas lahan yang diusahakan.

\section{Umur Petani Responden}

Keadaan penduduk berdasarkan kelompok umur dapat di bedakan menjadi dua kelompok yaitu penduduk usia produktif dan penduduk usia non produktif. Umur sangat mempengaruhi produksi dalam bekerja maupun peranannya dari berbagai alternatif pekerjaan yang dilakukan semakin bertambah usia seseorang, produktifitas kerjanya juga meningkat, namun melewati usia tertentu prodktifitas kerjanya akan semakin menurun seiring dengan bertambahnya umur.

Tabel 4 menjelaskan tentang umur dan jumlah petani yang menjadi sampel di Desa Matungkas
Tabel 4. Umur Petani yang Menjadi Sampel di Desa Matungkas

\begin{tabular}{cccc}
\hline No & $\begin{array}{c}\text { Kelompok } \\
\text { Umur (Tahun) }\end{array}$ & $\begin{array}{c}\text { Jumlah } \\
\text { (orang) }\end{array}$ & $\begin{array}{c}\text { Presentase } \\
(\boldsymbol{\%})\end{array}$ \\
\hline $\mathbf{1}$ & $25-40$ & 13 & 54,16 \\
$\mathbf{2}$ & $41-50$ & 9 & 37,50 \\
$\mathbf{3}$ & $\geq 60$ & 2 & 8,33 \\
& Jumlah & 24 & 100,00 \\
\hline
\end{tabular}

Sumber : Diolah dari data primer, 2016

Hasil penelitian diketahui bahwa jumlah petani responden yaitu 24 orang yang semuanya masih berusia produkstif. 13 orang atau 54,41 persen berada pada kisaran berumur 25-40 tahun, kemudian diikuti 9 orang atau 37,50 persen dengan kisaran umur 41-50. Sedangkan kisaran umur diatas 60 tahun berjumlah 2 orang atau 8,33 persen. Usia petani responden termasuk dalam usia produktif. Dimana usia berpengaruh terhadap produktifitas kerja petani, dengan banyaknya petani dalam kelompok umur produktif di suatu daerah memungkinkan daerah tersebut berkembang. Hal ini di sebabkan petani pada umumnya lebih cepat menerima informasi dan inovasi baru serta lebih cepat mengambil keputusan dalam penerapan teknologi baru yang berhubungan dengan usaha tani.

\section{Tingkat Pendidikan Petani}

Pendidikan petani responden merupakan salah satu faktor penting menerima dan menerapkan tekonologi baru disamping kemampuan dan keterampilan petani itu sendiri. Disamping itu sangat mempengaruhi pola pikir dan pengambilan keputusan dalam usahatani pepaya dan pemasaran yang dihasilkan. Tabel 5 menjelaskan tentang tingkat pendidikan petani yang membudidayakan pepaya yang menjadi sampel di Desa Matungkas.

Tabel 5. Tingkat Pendidikan Petani yang Menjadi Sampel

\begin{tabular}{llcc}
\hline No & $\begin{array}{c}\text { Tingkat } \\
\text { Pendidikan }\end{array}$ & $\begin{array}{c}\text { Jumlah } \\
\text { Petani } \\
\text { (orang) }\end{array}$ & $\begin{array}{c}\text { Presentase } \\
(\%)\end{array}$ \\
\hline $\mathbf{1}$ & SD & 14 & 58,33 \\
$\mathbf{2}$ & SLTP & 6 & 25,00 \\
$\mathbf{3}$ & SLTA & 4 & 16,67 \\
$\mathbf{4}$ & Perguruan Tinggi & - & - \\
& Jumlah & $\mathbf{2 4}$ & $\mathbf{1 0 0 , 0 0}$ \\
\hline
\end{tabular}

Sumber: Diolah dari data primer, 2016 
Hasil penelitian menunjukan bahwa presentase petani yang tamat SD sebesar 58,33 persen dari total jumlah petani responden, kemudian diikuti dengan tingkat pendidikan SLTP sebanyak 6 orang atau 25,00 persen. Sedangkan pada tingkat SLTA sebanyak 4 orang atau 16,67 persen. Presentase petani di Desa Matungkas yang hanya tamatan SD yang lebih dominan ini disebabkan karena masyarakat yang usia lanjut pada masa itu belum terfasilitasi untuk menempuh pendidikan yang lebih tinggi serta kurangnya kesadaran akan pentingnya pendidikan bagi sebagian penduduk, hal ini disebakan karena alasan ekonomi yang rendah, sehingga tidak mampu mengenyam pendidikan yang lebih tinggi.

Walaupun hanya tamatan sekolah dasar. Para petani mampu bertani pepaya dengan produksi yang cukup banyak. Ini dikarenakan para petani pepaya sudah lama mendapatkan keterampilan tersebut dengan mengikuti pelatihan dan saling berbagi pendapat pada para petani pepaya lain ataupun para orang tua yang sudah sejak lama mengetahui tentang cara bertani pepaya.

\section{Luas Penggunaan Lahan Usahatani Pepaya}

Luas lahan usaha tani merupakan keseluruhan luas lahan yang di usahakan petani responden baik milik sendiri, menyewa, maupun meyakap. Luas lahan hasil penelitian berada pada kisaran luas lahan 0,5-2 ha. Luas lahan usahatani menentukan pendapatan, taraf hidup dan derajat kesejahtraan rumah tangga petani, karena semakin luas lahan usahatani maka akan semakin tinggi hasil produksi sehingga turut meningkatkan pendapatan petani.

Tabel 6 menjelaskan tentang luas lahan garapan petani yang menajadi sampel di Desa Matungkas.

Tabel 6. Luas Pemilikan Lahan Garapan Petani Pepaya

\begin{tabular}{cccccc}
\hline No & $\begin{array}{c}\text { Luas } \\
\text { Tanam } \\
\text { (Ha) }\end{array}$ & Pohon & $\begin{array}{c}\text { Produksi } \\
\text { (trip/bulan) }\end{array}$ & $\begin{array}{c}\text { Jumlah } \\
\text { Petani } \\
\text { (orang) }\end{array}$ & $\begin{array}{c}\text { Presentase } \\
(\%)\end{array}$ \\
\hline $\mathbf{1}$ & 0,5 & 600 & 240 & 9 & 25,00 \\
$\mathbf{2}$ & 1 & 1.200 & 480 & 13 & 54,16 \\
$\mathbf{3}$ & 2 & 2.400 & 960 & 3 & 12,50 \\
& Jumlah & & & 24 & 100,00 \\
\hline
\end{tabular}

Sumber : Diolah dari data primer, 2016
Hasil penelitian menunjukan bahwa petani pepaya bisa berproduksi mencapai 4 tahun. Luas lahan yang dimemiliki petani yaitu 0,5 ha sebanyak 9 orang atau 25,00 persen. Lahan garapan 0,5 ha terdapat 600 pohon dalam satu bulan bisa di panen 2 kali. Kemudian diikuti dengan luas lahan satu ha sebanyak 13 orang atau 54,16 persen. Lahan garapan 1 ha terdapat 1200 pohon dalam satu bulan petani dapat memproduksi 4 kali sebanyak 480 buah. Sedangkan luas lahan 3 ha yang digarap petani sebanyak 3 orang atau 12,50 persen. Luas lahan 3 ha terdapat 2.400 pohon dalam satu bulan petani dapat memprodusksi 8 kali sebanyak 960. Produksi yang di hasilkan pada tiap lahan garapan berbeda-beda karena disebabkan oleh keadaan tanaman dan jumlah pohon yang di hasilkan. Dalam satu pohon dapat menghasilkan 2-3 buah

\section{Identitas Responden Lembaga Pemasaran}

Pedagang atau lembaga pemasaran yang terlibat dalam pemasaran pepaya di Desa Matungkas adalah pedagang pengumpul dan pedagang pengecer. Dari petani menjual pepaya ke pedagang pengumpul dan pedagang pengecer. Layaknya suatu pengalaman dan pola pikir yang cermat yang dalam hal ini umur dan pendidikan sangat mempengaruhi keberhasilan dalam berdagang.

\section{Pedagang Pengumpul}

Pedagang pengumpul pada umumnya mendapatkan pepaya langsung dari petani dengan cara sistem per trip. Tabel 7 menjelaskan tentang umur dan tingkat pendidikan pedagang pengumpul yang menjadi sampel di Desa Matungkas.

Tabel 7. Umur dan Tingkat Pedidikan Pedagang Pengumpul Yang Menjadi Sampel

\begin{tabular}{|c|c|c|c|}
\hline \multirow[t]{2}{*}{ No } & \multirow[t]{2}{*}{ Uraian } & \multicolumn{2}{|c|}{$\begin{array}{c}\text { Status Lembaga } \\
\text { Pemasaran }\end{array}$} \\
\hline & & $\begin{array}{c}\text { Pedagang } \\
\text { Pengumpul }\end{array}$ & $\begin{array}{c}\text { Presentase } \\
(\%)\end{array}$ \\
\hline 1 & Umur & & \\
\hline & a. $\quad 22-40$ & 2 & 33,33 \\
\hline & b. $41-50$ & 3 & 50,00 \\
\hline & c. $\quad \geq 60$ & 1 & 16,67 \\
\hline & Jumlah & 6 & 100,00 \\
\hline 2 & Tingkat Pendidikan & & \\
\hline & a. $\quad \mathrm{SD}$ & 3 & 50,00 \\
\hline & b. SLTP & 2 & 33,33 \\
\hline & c. SLTA & 1 & 16,67 \\
\hline & d. Perguruan Tinggi & - & - \\
\hline & Jumlah & 6 & 100,00 \\
\hline
\end{tabular}

Sumber : Diolah dari data primer, 2016 
Hasil penelitian diketahui bahwa umur responden pedagang pengumpul pepaya tergolong dalam usia produktif antara 22-40 tahun sebanyak dua orang atau 33,33 persen. Begitu juga kisaran 41-50 tahun sebanyak 3 orang atau 50,00 persen. Sedangkan kisaran umur diatas 60 tahun berjumlah 1 orang atau 16,67 persen.

Tingkat pendidikan responden pedagang pengumpul dalam pemasaran pepaya adalah tamatan SD sebanyak tiga orang atau 50,00 persen, Tamatan tingkat pendidikan SLTP sebanyak 2 orang atau 33,33 persen. Sedangkan pada tingkat SLTA sebanyak satu orang atau 16,67 persen. Tingkat pendidikan pada pedagang pengumpul yang mayoritas tamatan SD mempengaruhi strategi penjualan ke pedagang pengecer sehingga menjalankan kegiatan penjualan pepaya ke pedagang pengecer tidak melakukan grading pepaya, hal ini disebabkan karena kurangnya pengalaman dan tidak mau mengeluarkan biaya sortir.

\section{Pedagang Pengecer}

Tingkat umur seseorang sangat mempengaruhi kemampuanya untuk bekerja secara efektif. Tabel 8 ini menjelaskan tentang identitas dan tingkat pendidikan pedagang pengumpul yang menjadi sampel dalam penelitian di Desa Matungkas

Tabel 8. Identitas dan tingkat pendidikan Pedagang Pengecer Pepaya di Desa Matungkas

\begin{tabular}{ccc}
\hline $\mathbf{N}$ & Uraian & Status Lembaga \\
$\mathbf{0}$ & & Pemasaran \\
\hline
\end{tabular}

\begin{tabular}{|c|c|c|c|}
\hline & & $\begin{array}{l}\text { Pedagan } \\
\text { g } \\
\text { Pengecer }\end{array}$ & $\begin{array}{c}\text { Presentas } \\
\text { e } \\
(\%)\end{array}$ \\
\hline \multirow[t]{5}{*}{1} & Umur & & \\
\hline & a. $25-40$ & 4 & 26,67 \\
\hline & b. $41-50$ & 9 & 60.00 \\
\hline & c. $\geq 60$ & 2 & 13,34 \\
\hline & Jumlah & 15 & 100,00 \\
\hline \multirow[t]{6}{*}{2} & Tingkat Pendidikan & & \\
\hline & a. $\mathrm{SD}$ & 8 & 53,34 \\
\hline & b. SLTP & 5 & 33,34 \\
\hline & c. SLTA & 2 & 13,32 \\
\hline & $\begin{array}{ll}\text { d. } & \begin{array}{l}\text { Perguruan } \\
\text { Tinggi }\end{array}\end{array}$ & - & - \\
\hline & Jumlah & 15 & 100,00 \\
\hline
\end{tabular}

Hasil penelitian menunjukan variasi umur pedagang pengumul responden, dimana hasil penelitian di dapat umur relative yang bekerja adalah berumur 25-40 tahun yaitu sebanyak 4 orang atau 26,67 persen, kemudian diikuti dengan kelompok umur 41-50 sebanyak 9 orang atau 60,00 persen. Sedangkan kelompok umur diatas 60 tahun berjumlah 2 orang atau 13,34 persen. Tingkat pendidikan SD sebanyak 8 orang atau 53,34 persen, kemudian diikuti dengan tingkat pendidikan SLTP sebanyak 5 orang atau 33,34 persen. Sedangkan pada tingkat SLTA sebanyak 2 orang atau 13,32 persen.

\section{Fungsi lembaga pemasaran}

Fungsi-fungsi pemasaran adalah mengusahakan agar pembeli atau konsumen memperoleh barang yang diinginkan pada tempat, waktu, dan harga yang tepat. Fungsi-fungsi pemasaran dalam pelaksanaan aktifitasnya dilakukan oleh lembaga-lembaga pemasaran. Lembaga pemasaran ini yang akan terlibat dalam proses penyampaian barang dan jasa dari produsen sampai ke tangan konsumen. Fungsifungsi pemasaran meliputi fungsi pertukaran, fungsi fisik dan fungsi fasilitas. Tabel 9 menjelaskan tentang fungsi-fungsi lembaga pemasaran yang berada pada pola saluran pemasaran.

Tabel 9. Fungsi Lembaga Pemasaran Pepaya di Desa Matungkas

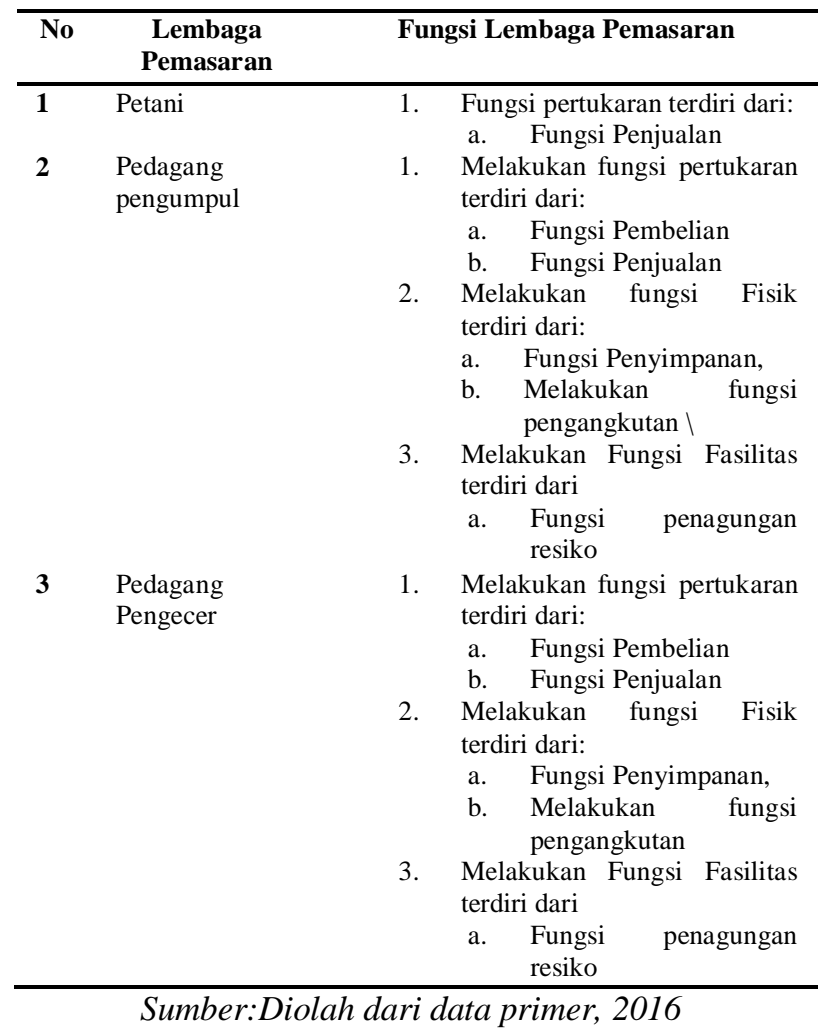




\section{a. Petani}

Produsen pepaya umumnya melakukan fungsi pertukaran yaitu kegiatan penjualan dengan cara menjual produksi pepaya ke pasar-pasar tradisional. Produsen menjual pepaya produksinya kepada pedagang pengumupul, dan kadangkala menjual langsung kepada pedagang pengecer. Tujuannya adalah mendapatkan tingkat harga yang lebih baik dalam melakukan kegiatan pemasaran.

\section{b. Pedagang Pengumpul}

Pedagang pengumpul melakukan fungsi pertukaran yaitu membeli pepaya dari produsen dan menjual kembali kepada pedagang pengecer. Fungsi fisik yaitu: (1) fungsi penyimpanan dilakukan apabila sewaktu-waktu pepaya yang di jual pedagang pengumpul tidak laku terjual. (2) fungsi pengangkutan dilakukan menggunakan mobil bak terbuka (Daihatsu Gran $\mathrm{Max} \mathrm{Pu}$ ). Fungsi fasilitas yaitu fungsi penaggungan resiko adalah pedagang pengumpul menanggung resiko adanya pepaya yang rusak, selama proses pengangkutan dan resiko barang yang diangkut tidak habis terjual

\section{c. Pedagang Pengecer}

Pedagang pengecer malakukan fungsi pertukaran yakni kegiatan pembelian dari pihak produsen dan pedagang pengumpul, dan melakukan penjualan langsung kepada konsumen dalam bentuk pepaya utuh (belum diolah) ungsi fisik yaitu: (1) fungsi penyimpanan dilakukan apabila sewaktu-waktu pepaya yang di jual pedagang pengumpul tidak laku terjual. (2) fungsi pengangkutan dilakukan menggunakan mobil bak terbuka (Daihatsu Gran $\mathrm{Max} \mathrm{Pu}$ ). Fungsi fasilitas yaitu fungsi penaggungan resiko adalah pedagang pengumpul menanggung resiko adanya pepaya yang rusak, selama proses pengangkutan dan resiko barang yang diangkut tidak habis terjual

\section{Pemasaran Pepaya}

Pepaya memiliki nama latin (Carica Papaya l) merupakan tanaman yang berasal dari meksiko bagian selatan. Tanaman pepaya merupakan tanaman yang sedang dicendrungi dan mulai banyak dikebunkan para petani pada saat ini karena sangat menjanjikan keuntungan. Pepaya bisa di panen stelah berumur 8-9 bulan. Pohonnya dapat berbuah hingga umur mencapai empat tahun. Dalam satu bulan bisa di panen empat kali.
Sekali panen setiap pohon pepaya dapat menghasilkan 2 hingga 3 buah.

Panen raya berlangsung setiap tiga kali dalam setahun yaitu, bulan Juni, Juli, Agustus, namum produksi pepaya berlangsung sepanjang tahun walaupun hanya dalam jumlah sedikit. Bahkan ada petani karena desakan kebutuhan ekonomi memanen pepaya empat kali dalam setahun. Akibatnya kualitas produk yang dihasilkan tidak maksimal sehingga nilai jualnya pun tidak maksimal.

Buah pepaya yang di pasarkan di Desa Matungkas umumnya masih berbentuk utuh (belum diolah). Petani dapat menjual buah pepaya kepada pedagang pengumpul di tingkat kecamatan yang berada di desa atau di jual ke pedagang pengecer di kabupeten dan propinsi dan juga petani bisa menjual di kios-kios di depan rumah petani. Bila di lihat dari segi transportasi, bisa dikatakan bahwa transportasi dari desa ke pedagang pengecer kabupaten dan pedagang pengecer di propinsi sudah cukup lancar. Harga yang terbentuk dari pedagang pegumpul dan pedagang pengecer sudah melalui kesepakatan antar pedagang. Harga di pedagang pengumpul dan pedagang pengecer berbeda karena adanya biaya-biaya.

Pedagang pengumpul dan pedagang pengecer langsung datang ke petani untuk membeli pepaya. Pepaya yang di jual petani dihitung per trip, satu trip 120 buah. Pedagang pegumpul menjual ke pedagang pengecer di pasar tradisional yang berada di propinsi (pasar bersehati, pasar karombasan). Petani menjual juga ke pedagang pengecer yang ada di kabupaten dan propinsi.

\section{Saluran Pemasaran}

Kegiatan pendistribusian pepaya dari petani ke konsumen memerlukan pedagang perantara atau disebut juga sebagai lembaga pemasaran yang mempunyai peranan penting dalam kegiatan pemasaran. Penyaluran hasil produksi dari produsen ke konsumen melalui lebih dari satu saluran pemasaran dimana masingmasing saluran melibatkan lembaga pemasaran yang tidak sama. Ada saluran yang melibatkan banyak lembaga pemasaran sehingga saluran pemasaran menjadi panjang da nada juga saluran pemasaran yang melibatkan sedikit lembaga pemasaran sehingga pemasaran menjadi pendek.

Saluran pemasaran pepaya di Desa Matungkas melibatkan tiga lembaga pemasaran, yakni produsen, pedagang pengumpul, pedagang 
pengecer di desa, pedagang pengecer di kabupeten dan pedagang pengecer di propinsi (pasar tradisional). Lembaga pemasaran yang terlibat dalam saluran pemasaran pepaya ini harus melakukan fungsi-fungsi pemasaran, dengan adanya fungsi-fungsi pemasaran dapat mempermudah konsumen untuk mendapatkan apa yang mereka butuhkan. Dalam pemasaran, barang mengalir dari produsen sampai kepada konsumen akhir yang di sertai penambahan guna tempat melalui proses pengangkutan dan guna waktu melalui proses penyimpanan.

Saluran pemasaran pepaya berdasarkan penelitian di Desa Matungkas Kecamatan Dimembe adalah sebagai berikut:

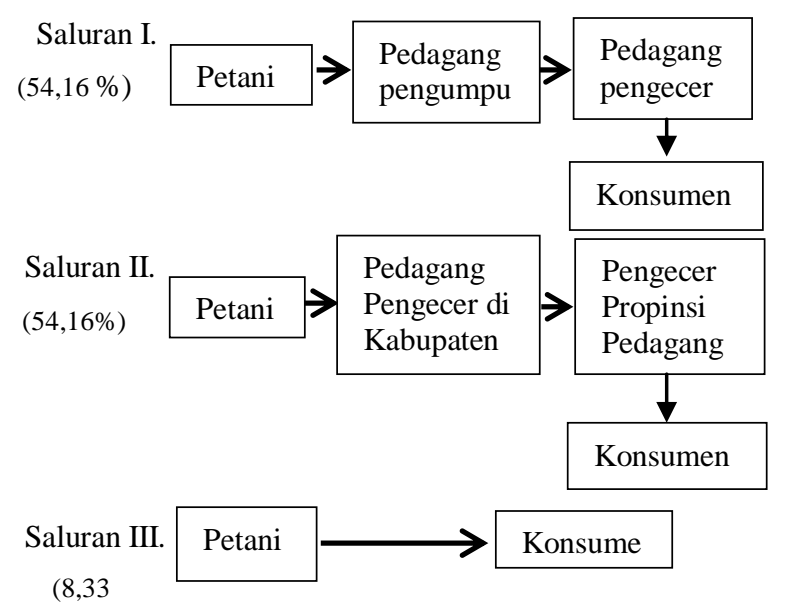

Gambar 3

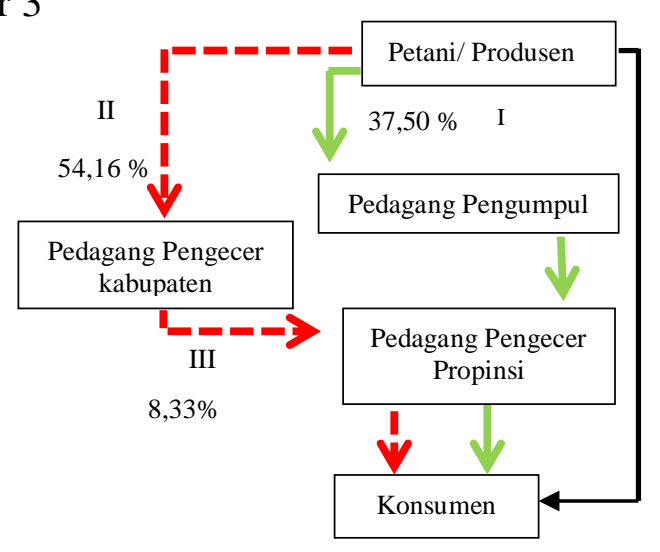

Gambar 3: Pola Saluran Pemasaran Pepaya di Desa Matungkas

Keterangan:

1. Saluran Pemasaran I

Pola saluran pemasaran I terdapat 3 alur yaitu: petani-pedagang pengumpulpedagang pengecer-konsumen adalah sebanyak 9 orang atau 37,50 persen dari 24 responden petani. Saluran pemasaran pertama ini menggunakan dua lembaga pemasaran di antara produsen dan konsumen, yakni pedagang pengumpul sebanyak 6 orang dan pedagang pengecer sebanyak 5 orang. Pedagang pengumpul membeli dari petani bertahap, umumnya pedagang pengumpul membeli pepaya dalam jumlah yang lebih banyak, yaitu berkisar 2-3 per trip atau 240-360 per buah. Pedagang pengumpul menjual pepayanya kepada pedagang pengecer di propinsi (pasar Bersehati dan pasar Karombasan) yang ada di pasar tradisional yaitu berkisar satu per trip atau 120 per buah. Pedagang penegecer di propinsi tinggal menunggu pepaya yang di bawah pedagang pengumpul (berlanganan)

Harga jual pepaya dari produsen ke pedagang pengumpul berkisar antara $\mathrm{Rp}$ 10.000 per buah, dan harga jual pedagang pengumpul ke pedagang pengecer berkisar antara Rp 15.000-20.000 per buah, dan harga jual kepada konsumen berkisar antara Rp 18.000-25.000 per buah. Ini berarti ratarata harga jual pepaya dari pedagang pengumpul sebesar Rp 17.000 perbuah dan rata-rata harga jual pedagang pengecer ke konsumen akhir sebesar Rp 20.000 perbuah.

\section{Saluran Pemasaran II}

Pola saluran pemasaran II terdiri dari petani, pedagang, dan pengecer kabupaten/ propinsi-konsumen. Petani yang memilih pola saluran ini sebanyak 13 orang $(54,16$ persen) dari 24 petani responden. Petani sebagai penjual tidak mengeluarkan biaya transportasi akan tetapi biaya transportasi di tanggung oleh pedagang pengecer. Pada saluran pemasaran II petani langsung menjual ke pedagang pengecer yang ada di kabupaten (pasar Airmadidi) dan dipropinsi (pasar Bersehati, pasar Karombasan).

Kegiatan penjualan dengan cara pedagang pengecer mendatangi petani di kebun. Adapun cara pembayaran yang di lakukan dari pedagang pengecer ke petani dengan cara pembayaran tunai setelah menerima pepaya. Pengangkutan pepaya mengunakan alat transportasi mobil bak terbuka (Daihatsu Gran Max Pu). Selain pepaya pedagang pengecer membawah produk-produk pertanian (sayur-sayuran, 
pisang dan lainnya) ke pasar tradisional. Waktu pengangkutan pepaya dari petani ke pedagang pengecer berkisar jam 4 sore, selanjutnya untuk membawah pepaya dan hasil-hasil produk pertanian lainnya ke pasar tradisional yaitu jam 1 malam.

Harga jual pepaya dari produsen ke pedagang pengecer berkisar antara $\mathrm{Rp}$ 10.000 per buah, dan harga jual pepaya dari pedagang pengecer ke konsumen berkisar antara Rp 18.000-25.000 per buah. Ini berarti rata-rata harga jual pepaya dari pedagang pengecer ke konsumen akhir sebesar Rp 20.000 perbuah

\section{Saluran Pemasaran III}

Pola saluran pemasaran III (petani-konsumen) sebanyak 2 orang (8,33 persen). Saluran Pemasaran yang ke tiga ini merupakan saluran pemasaran dengan volume penjualan paling kecil dari produsen. Saluran pemasaran ini tidak menggunakan lembaga pemasaran manapun, dan oleh karena itu merupakan saluran yang memiliki rantai paling pendek. Saluran pemasaran ini tidak menggunakan lembaga pemasaran dan oleh karena itu merupakan saluran yang memiliki rantai pemasaran paling pendek, dimana petani langsung menjual pepaya kepada konsumen, melalui kios-kios di jalan (dirumah) dan juga menjual di pasar tradisonal. Petani juga berperan sebagai 'pedagang pengumpul dan pedagang pengecer.

Pada saluran pemasaran III ini, harga jual pepaya dari produsen ke konsumen pada bulan Maret 2016 berkisar antara $\mathrm{Rp} 18.000-25.000$ atau $2-5 \mathrm{~kg}$.
Saluran pemasaran III ini memiliki sasaran konsumen yang berada di sekitar lokasi budidaya produsen, yakni konsumen yang sewaktu-waktu ingin membeli pepaya Segar tanpa harus ke pasar dan juga produsen juga membawah pepaya ke pasar tradisional baik pasar di kabupaten maupun pasar di propinsi.

Adapun jumlah petani berdasarkan saluran pemasaran buah pepaya yang digunakan dalam mendistribusikan buah pepaya dapat dilihat pada Tabel 10.

Hasil penelitian menunjukan bahwa saluran pemasaran II merupakan saluran yang paling banyak digunakan oleh petani yaitu sebesar 13 petani responden atau 50,00 persen dari 24 petani. Hal ini disebabkan petani lebih memilih menjual pepaya langsung ke pedagang pengecer di kabupaten dan propinsi karena setiap hasil panen pedagang pengecer mendatangi petani untuk membeli pepaya (berlangganan dengan petani) dan pembayarannya secara tunai. Sehingga petani tidak menanggung resiko selama belum dipanen dan petani lebih memilih mengalokasikan waktunya untuk kegiatan menambah penghasilan lainya, serta tidak mengeluarkan biaya yang lebih besar. Hal ini dikarenakan biaya pengangkutan di tanggung pedagang pengecer, maka petani pepaya tidak khwatir hasil produknya tidak terjual.

Saluran pemasaran II merupakan saluran terbesar kedua yaitu sebesar 37,50 persen. Saluran pemasaran ini menujukkan bahwa petani memilih menjual pepaya kepada pedagang pengumpul. Hal ini dilakukan karena petani tidak mau mengeluarkan biaya lagi. Sehingga yang menanggung biaya pengangkutan adalah pedagang pengumpul yang mendatangi petani. pembayaran dilakukan ketika pepaya sudah terjual di pasar tradisional.

Tabel 10. Jenis Saluran Pemasaran dan Jumlah Petani Responden di Desa Matungkas Kecamatan Dimembe

\begin{tabular}{cccc}
\hline No & Saluran Pemasaran & Jumlah Petani & $\begin{array}{c}\text { Presentase } \\
(\boldsymbol{\%})\end{array}$ \\
\hline $\mathbf{1}$ & Saluran I & 9 & 37,50 \\
$\mathbf{2}$ & Saluran II & 13 & 54,16 \\
$\mathbf{3}$ & Saluran III & 2 & 8,34 \\
& Jumlah & $\mathbf{2 4}$ & $\mathbf{1 0 0 , 0 0}$ \\
\hline
\end{tabular}

Sumber: Diolah dari data primer, 2016 
Saluran pemasaran III merupakan saluran yang lebih kecil yaitu sebesar 8,34 persen sebanyak 2 orang petani. Saluran pemasaran III petani sendiri yang menjual pepaya ke konsumen akhir.

Marjin pemasaran meupakan perbedaan harga ditingkat petani atau produsen dan harga ditingkat konsumen. Termasuk dalam marjin pemasaran ini adalah seluruh biaya yang dikeluarkan oleh lembaga pemasaran mulai dari tingkat petani atau prosusen sampai pedagang pengumpul dan pedagang pengecer dalam proses pemasaran

\section{a).Marjin Pemasaran pada Saluran Pemasaran Model Pertama}

Melalui observasi langsung dilapangan di dapat 9 sampel petani yang menjual pepaya ke pedagang pengumpul, menurut informasi dari petani maka didapat 6 sampel pedagang pengumpul dan 5 sampel pedagang pengecer di propinsi yaitu pasar bersehati dan pasar karombasan. Dengan asumsi satu trip kurang lebih 120 buah pepaya, harga satu trip sebesar Rp 1.200.000 dan harga jual pepaya dari produsen ke pedagang pengumpul berkisar antara $\mathrm{Rp} 10.000$ per buah, dan harga jual pedagang pengumpul ke pedagang pengecer berkisar antara Rp 15.00020.000 per buah, dan harga jual kepada konsumen berkisar antara Rp 18.000-25.000 per buah. Ini berarti rata-rata harga jual pepaya dari pedagang pengumpul sebesar Rp 17.000 perbuah dan ratarata harga jual pedagang pengecer ke konsumen akhir sebesar Rp 20.000 perbuah.

Tabel 11 menjelaskan harga, biaya dan marjin pemasaran pada pola saluran pemasaran satu. Hasil penelitian menunjukan bahwa marjin pemasaran yang terbentuk dari selisih harga jual pepaya antara pedagang pengumpul dan produsen sebesar Rp 8.640.000/trip atau 40,00 persen di tingkat pedagang pengumpul dan di tingkat pedagang pengecer sebesar Rp2.160.000/trip. Dimana harga di tingkat petani Rp 10.800.000/trip. Di dapat dari Sembilan sampel petani. Berdasarkan analisis marjin tersebut dapat di ketahui bahwa marjin terbesar terjadi pada pedagang pengumpul. Nilai marjin yang besar ini di karenakan semakin banyaknya lembaga yang pemasaran yang terlibat dalam proses pemasaran pepaya.

Tabel 11. Rata-Rata Biaya, Keuntungan dan Marjin Pemasaran Pepaya Pada Saluran Pemasaran I di Desa Matungkas

\begin{tabular}{|c|c|c|c|c|c|}
\hline No & Pola Saluran Pemasaran & Rp/Trip & Rp/Buah & $\begin{array}{c}\text { Distribusi } \\
\text { Marjin } \\
\text { (Rp/trip) } \\
\end{array}$ & $\begin{array}{c}\text { Presentase } \\
(\%)\end{array}$ \\
\hline \multirow[t]{2}{*}{1} & Petani & & & & \\
\hline & Harga Jual & 10.800 .000 & 10.000 & 8.640 .000 & 40,00 \\
\hline \multirow[t]{7}{*}{2} & Pedagang Pengumpul & & & & \\
\hline & a. Transportasi & 500.000 & & & 2,57 \\
\hline & b. Retribusi & 12.000 & & & 6 \\
\hline & c. Makan & 240.000 & & & 1,23 \\
\hline & Total Biaya & 752.000 & & & 4,05 \\
\hline & Profit Marjin & 7.888 .000 & & & 40,57 \\
\hline & Harga Jual & 19.440 .000 & 18.000 & & - \\
\hline \multirow[t]{9}{*}{3} & Pedagang Pengecer & & & 2.160 .000 & \\
\hline & a. Pengangkutan & 85.000 & & & 39 \\
\hline & b. Retribusi & 85.000 & & & 39 \\
\hline & c. Pembungkus & 42.000 & & & 19 \\
\hline & d. Makan & 105.000 & & & 48 \\
\hline & Total Biaya & 317.000 & & & 1,47 \\
\hline & Keuntungan Marjin & 1.843 .000 & & & 8,53 \\
\hline & Harga Jual & 21.600 .000 & 20.000 & & \\
\hline & Total Marjin & & & 10.800 .000 & \\
\hline
\end{tabular}

Sumber:Diolah dari data primer, 2016 
Hal ini diakibatkan oleh tingginya biaya transportasi yang harus di tanggung oleh pedagang pengumpul dalam melakukan pemasaran pepaya ke pedagang pengecer di propinsi (pasar bersehati dan pasar karombasan) sebesar Rp 500.000/trip. Didapat dari enam sampel pedagang pengumpul (lihat dilampiran 3) dan biaya-biaya lainnya seperti biaya retribusi yaitu uang parkir sebesar Rp 12.000/trip, dan biaya makan sebesar Rp 240.000/trip. Total biaya yang di keluarkan oleh pedagang pengumpul sebesar Rp 788.000/trip. Profit marjin yang di peroleh pedagang pengumpul sebesar $\mathrm{Rp}$ 7.854.000/ trip.

Sedangkan untuk pedagang pengecer mengeluarkan biaya pengangkutan (Roda-roda) hanya sebesar Rp 50.000/trip karena pedagang pengumpul membawah langsung ke pedagang pengecer di propinsi (pasar bersehati dan pasar karombasan) dan biaya lain-lainnya seperti biaya retribusi yaitu biaya parkir, bea sampah, bea tempat sebesar Rp 45.000/trip, biaya pembungkus (tas plastik) sebesar Rp 36.000/trip, biaya makan sebesar Rp 65.000/trip. Total biaya yang di keluarkan pedagang pengecer sebesar $\mathrm{Rp}$ 178.000/trip. Didapat dari dua sampel pedagang pengecer (lihat di lampiran 4) Resiko yang di tangung pedagang pengecer yaitu pepaya busuk, tidak laku terjual di pasar dan persaingan serta permintaan penawaran pasar. Semakin lama buah pepaya di pasarkan maka semakin besar resiko yang di keluarkan. Dan keuntungan yang di dapat pedagang pengecer dalam memasarkan pepaya sebesar Rp 1.982.000. Semakin panjang lembaga pemasaran yang terliobat maka harga yang di terima petani akan semakin rendah.

Tabel 12. Rata-Rata Biaya dan Marjin Pemasaran Pepaya Pada Saluran Pemasaran II di Desa Matungkas

\begin{tabular}{|c|c|c|c|c|c|}
\hline No & Pola Saluran Pemasaran & Rp/Trip & Rp/Buah & $\begin{array}{c}\text { Distribusi } \\
\text { Marjin } \\
\text { (Rp) }\end{array}$ & $\begin{array}{c}\text { Presentase } \\
(\%)\end{array}$ \\
\hline \multirow[t]{2}{*}{1} & Petani & & & & \\
\hline & Harga Jual & 6.000 .000 & 10.000 & 4.200 .000 & 58,82 \\
\hline \multirow[t]{8}{*}{2} & $\begin{array}{l}\text { Pedagang Pengecer di } \\
\text { kabupaten }\end{array}$ & & & & \\
\hline & a. Transportasi & 150.000 & & & 1,47 \\
\hline & b. Retribusi & 36.000 & & & 35 \\
\hline & c. Makanan & 60.000 & & & 58 \\
\hline & d. Pengemasan & 30.000 & & & 29 \\
\hline & Total Biaya & 276.000 & & & 2,70 \\
\hline & Profit Marjin & 3.924 .000 & & & 38,47 \\
\hline & Harga Jual & 10.200 .000 & 17.000 & & - \\
\hline \multirow[t]{2}{*}{1} & Petani & & & & \\
\hline & Harga Jual & 9.600 .000 & 20.000 & 9.600 .000 & 50,00 \\
\hline \multirow[t]{8}{*}{2} & $\begin{array}{l}\text { Pedagang Pengecer di } \\
\text { propinsi }\end{array}$ & & & & \\
\hline & a. Transportasi & 500.000 & & & 2,08 \\
\hline & b. Retribusi & 68.000 & & & 35 \\
\hline & c. Makanan & 80.000 & & & 41 \\
\hline & d. Pengemasan & 36.000 & & & 18 \\
\hline & Total Biaya & 584.000 & & & 3,04 \\
\hline & Profit Marjin & 9.016 .00 & & & 46,95 \\
\hline & Harga Jual & 19.200 .000 & & & - \\
\hline
\end{tabular}

Sumber: Diolah dari data primer, 2016 
Farmer share merupakan harga yang diterima petani atau perbandingan antara harga yang diterima petani dengan harga yang diterima konsumen. Farmer share pada saluran I adalah 42,22 persen dan harga di tingkat pedagang pengecer sebesar $\mathrm{Rp} 21.600 .000 /$ trip. Untuk mengukur efisiensi pemasaran yaitu apabila bagian yang di terima petani $\leq 50 \%$ berarti pemasaran belum efisien dan bila bagian yang di terima produsen $\geq 50 \%$ maka pemasaran dikatakan efisien. Melihat nilai farmer share yang $\leq 50 \%$ maka saluran pemasaran satu belum efisien.

\section{b). Marjin Pemasaran Pada Saluran Pemasaran kedua}

Melalui observasi langsung dilapangan di dapat 13 sampel petani responden, 3 pedagang pengumpul di kabupaten dan 5 pedagang pengumpul di propinsi. Dengan asumsi satu trip 120 buah dengan harga $\mathrm{Rp} 1.200 .000$. Harga jual pepaya dari produsen ke pedagang pengecer berkisar antara $\mathrm{Rp}$ 10.000 per buah, dan harga jual pepaya dari pedagang pengecer di kabuapten ke konsumen akhir berkisar antara Rp 15.000-20.000 per buah, sedangkan harga jual pepaya di pedagang pengecer yang ada di propinsi berkisar Rp 17.000-25.000 per buah. Ini berarti rata-rata harga jual pepaya dari pedagang pengecer di kabupaten sebesar Rp 17.000 perbuah ke konsumen akhir dan rata-rata harga jual pedagang pengecer di propinsi ke konsumen akhir sebesar Rp 20.000 perbuah.

Tabel 12 menjelaskan harga, biaya dan marjin pemasaran pada pola saluran pemasaran kedua. Hasil penelitian ini menunjukan bahwa petani menjual pepaya kepada pedagang pengecer di kabupaten dan pedagang pengecer di propinsi. Rata-rata total harga jual pepaya dari petani ke pedagang pengecer di kabupaten sebesar $\mathrm{Rp}$ 6.000.000/trip atau 50.000/buah. Didapat dari lima sampel pedagang pengecer di kabupaten sedangkan harga jual petani ke pedagang pengecer di propinsi sebesar Rp 9.600.000/trip atau $\mathrm{Rp} \mathrm{80.000/buah.} \mathrm{Didapat} \mathrm{dari} 8$ sampel pedagang pengecer di propinsi.

Total biaya yang di keluarkan oleh pedagang pengecer di Kabupaten untuk memasarkan pepaya sebesar Rp 276.000/trip. Di dapat dari tiga sampel. Dimana total biaya di dapat dari biaya pemasaran yang dikeluarkan meliputi biaya trasportasi sebesar $\mathrm{Rp}$ 150.000/trip di mana pedagang pengecer membawah pepaya ke pasar Airmadidi.

Pedagang pengecer mendatangi petani pepaya di kebun. Kemudian ada biaya retribusi merupakan biaya yang dikeluarkan oleh pedagang pengecer untuk membayar keamanan, kebersihan dan pajak di pasar dan uang parkir sebesar $\mathrm{Rp}$ 36.000/trip, pemungutannya dilakukan setiap kali pedagang pengecer menjual pepaya. Biaya pengemasan adalah biaya yang dikeluarkan untuk membeli plastik sebesar Rp 30.000/trip. Pedagang penegecer juga mengeluarkan uang makan sebesar Rp 60.000/trip.

Total biaya yang di keluarkan oleh pedagang pengecer di Propinsi sebesar $\mathrm{Rp}$ 584.000/trip. Di dapat dari 5 sampel. Biaya yang di keluarkan meliputi biaya transportasi,biaya retribusi,biaya makan dan biaya pengemasan. Perbedaan biaya antara pedagang penegecer di kabupaten dan pedagang pengecer di propinsi terletak di biaya transportasi. Karena jarak yang di tempuh untuk memasarkan pepaya oleh pedagang pengecer di propinsi lebih jauh dari pedagang pengecer yang hanya memasarkan di kabupaten. Resiko yang di tanggung oleh pedagang pengecer yaitu perubahan selera konsumen, busuk, tidak laku dipasar dan persaingan serta permintaan penawaran dipasar.

Marjin pemasaran pedagang pengecer pepaya di kabupaten sebesar Rp 4.200.000/trip sedangkan pada pedagang pengecer di propinsi sebesar Rp 9.600.000/trip. Besarnya nilai marjin ini disebabkan oleh besarnya biaya pemasaran. Dari saluran pemasaran II memiliki marjin pemasaran yang rendah hal ini ditunjukkan dengan nilai farmer share dari pedagang pengecer sebesar $58,82 \%$ sehingga pendapatan yang diterima petani (farmer share) tinggi. Untuk mengukur efisiensi pemasaran yaitu apabila bagian yang di terima petani $\leq 50 \%$ berarti pemasaran belum efisien dan bila bagian yang di terima produsen $\geq 50 \%$ maka pemasaran dikatakan efisien. Melihat nilai farmer share yang $\leq$ $50 \%$ maka saluran pemasaran kedua dikatakan efisien. Profit marjin yang di peroleh pedagang pengecer di kabupaten sebesar Rp 3.924.000/trip sedangkan pada pedagang pengecer di propinsi sebesar Rp 9.016.000/trip.

\section{c). Marjin Pemasaran Pada Saluran Pemasaran ketiga}

Marjin pemasaran merupakan selisih harga jual di tingkat petani terhadap harga beli konsumen. Besar kecilnya nilai marjin pemasaran pada masing-masing saluran berbeda-beda, hal ini tergantung dari panjang pendeknya lembaga pemasaran yang terlibat di dalamnya. Saluran pemasaran ketiga ini adalah saluran pemasaran yang paling pendek.

Tabel 13 menjelaskan harga, biaya dan marjin pemasaran pada pola saluran pemasaran ketiga. 
Tabel 13. Rata-rata Biaya dan Marjin Pemasaran Pepaya Pada Saluran Pemasaran III di Desa Matungkas

\begin{tabular}{|c|c|c|c|c|c|}
\hline No & Pola Saluran Pemasaran & Rp/Trip & Rp/Buah & $\begin{array}{c}\text { Distribusi } \\
\text { Marjin } \\
\text { (Rp) }\end{array}$ & $\begin{array}{c}\text { Presentase } \\
(\%)\end{array}$ \\
\hline \multirow[t]{9}{*}{1} & Petani & & & & \\
\hline & Harga Jual & 2.400 .000 & 20.000 & 2.400 .000 & 100.00 \\
\hline & a. Transportasi & 70.000 & & & 1,45 \\
\hline & b. Retribusi & 12.000 & & & 25 \\
\hline & c. Uang Makan & 40.000 & & & 83 \\
\hline & d. Pembungkus & 18.000 & & & 37 \\
\hline & Total Biaya & 140.000 & & & 2,91 \\
\hline & Profit Marjin & 2.260 .000 & & & 47,08 \\
\hline & Harga Jual & 4.800 .000 & 420.000 & & \\
\hline
\end{tabular}

Sumber: Diolah dari data primer, 2016

Hasil penelitian menunjukan bahwa saluran pemasaran ketiga ini merupakan saluran pemasaran dengan volume penjualan paling kecil, saluran pemasaran ini tidak menggunakan lembaga pemasaran, dan oleh karena itu merupakan saluran yang memiliki rantai pemasaran paling pendek. Penelitian di lakukan pada bulan maret 2016. Dengan harga pepaya yang tinggi yaitu sebesar Rp 1.200.000/trip, karena produksi pepaya sedikit, maka harga naik dan persaingan dengan produk local (langsa,mangga dan manggis) sedikit. Produk pepaya yang di jual petani habis terjual. Meskipun tidak habis, petani akan menyuruh pemborong yang sudah berlangganan membeli pepaya dengan harga yang murah, karena petani sudah menghitung keuntungan yang di dapat. Pepaya bisa bertahan sampai dua hari. Dari hasil yang di dapat bahwa margin pemasaran pada saluran ketiga adalah sebesar $\mathrm{Rp}$ 2.400.000/trip. Di dapat dari dua sampel petani (lihat di lampiran 3).Total biaya yang di keluarkan oleh produsen untuk memasarkan pepaya sebesar Rp Rp 140.000/trip. Di dapat dari dua sampel petani (lihat di lampiran 8).

Biaya pemasaran yang dikeluarkan meliputi biaya trasportasi sebesar $\mathrm{Rp}$ 70.000/trip di mana produsen membawah pepaya ke pasar dan ada juga yang menjual dikios-kios depan rumah. Kemudian biaya retribusi merupakan biaya yang dikeluarkan oleh petani ketika membawah pepaya ke pasar yaitu uang membayar keamanan, kebersihan dan uang parkir sebesar Rp 12.000/trip, pemungutannya dilakukan setiap kali pedagang produsen menjual pepaya. Biaya pengemasan adalah biaya yang dikeluarkan untuk membeli plastik sebesar Rp 18.000/trip. Produsen juga mengeluarkan uang makan sebesar Rp 40.000/trip.

Resiko yang di tangung produsen yaitu pepaya busuk, tidak laku terjual di pasar dan persaingan serta permintaan penawaran pasar. Semakin lama buah pepaya di pasarkan maka semakin besar resiko yang di keluarkan dan keuntungan yang diperoleh sebesar Rp 2.260.000/trip dari harga beli konsumen pada saluran ini. Biaya pemasaran yang relatif kecil menunjukkan bahwa saluran ini sudah cukup efisien. Produsen sebagai satu-satunya lembaga pemasaran pada saluran ini mendapatkan seluruh margin dan keuntungan. Adapun farmer share yang terjadi pada saluran ini sebesar 100 persen, menunjukkan bahwa bagian yang diterima petani pepaya sudah paling maksimal dan memberikan insentif penuh bagi produsen.

Tabel 14 menjelaskan bahwa rekapitulasi marjin dan farmer share di tiap saluran pemasaran di Desa Matungkas

Hasil penelitian menunjukan bahwa marjin pemasaran pada saluran pertama sebesar Rp 8.640.000/trip dan farmer share sebesar 40,00 persen di pedagang penumpul dan saluran pemasaran kedua marjin pemasaran pada pedagang pengecer di kabupaten sebesar Rp 4.200.000 dan farmer share 58,82 persen sedangkan marjin pemasaran pada pedagang pengecer di propinsi sebesar Rp 9.600.000/trip dan farmer share 50,00 persen. Marjin pada saluran pemasaran ketiga sebesar Rp 2.400.000 dan farmer share 100 persen. 
Tabel 14. Rekapitulasi Marjin dan Farmer Share di Tiap Saluran Pemasaran

Saluran Pemasaran I Saluran Pemasaran II $\quad$ Saluran Pemasan III

Uraian

$\begin{array}{cccccc}\text { MP } & \text { FS } & \text { MP } & \text { FS } & \text { MP } & \text { FS } \\ (\mathbf{R p}) & (\boldsymbol{\%}) & (\mathbf{R p}) & (\boldsymbol{\%}) & (\mathbf{R p}) & (\boldsymbol{\%})\end{array}$

Produsen

2.400 .000

100,00

\begin{tabular}{|c|c|c|c|c|c|c|}
\hline $\begin{array}{l}\text { Pedagang } \\
\text { pengumpul }\end{array}$ & 8.640 .000 & 40.00 & & & & \\
\hline $\begin{array}{l}\text { Pedagang } \\
\text { pengecer } \\
\text { dikabupaten }\end{array}$ & & & 4.200 .000 & 58,82 & & \\
\hline $\begin{array}{l}\text { Pedagang } \\
\text { pengecer di } \\
\text { propinsi }\end{array}$ & 2.160 .000 & & 9.600 .000 & 50.00 & & \\
\hline $\begin{array}{l}\text { Total } \\
\text { Farmer share }\end{array}$ & & 40.00 & & 100,82 & & \\
\hline $\begin{array}{l}\text { Total } \\
\text { Marjin } \\
\text { Pemasaran }\end{array}$ & 10.800 .000 & & 13.800 .000 & & 2.400 .000 & 100,00 \\
\hline
\end{tabular}

Keterangan:

MP = Marjin Pemasaran FS $=$ Farmer Share

Dilihat dari rekapitulasi marjin dan pemasaran. Saluran pemasaran yang paling efisien adalah saluran pemasaran dua dan ketiga adalah saluran yang sangat menguntungkan bagi petani. Dimana saluran pemasaran kedua, marjin pemasaran $\mathrm{Rp}$ 4.200 .000 dan farmer share 58,82 di pedagang pengecer dikabupaten dan pedagang pengecer di propinsi Rp 9.600.000/trip dan farmer share 50,00 persen dimana marjin pemasaran rendah dan farmer share tinggi. Pedagang pengecer mendatangi petani dan cara pemabayaran secara tunai,

Saluran pemasaran ketiga petani sendiri yang menjual buah pepaya ke konsumen dan resiko yang di tangung produsen yaitu pepaya busuk, tidak laku terjual di pasar dan persaingan serta permintaan penawaran pasar. Semakin lama buah pepaya di pasarkan maka semakin besar resiko yang di keluarkan. Marjin pemasaran sebesar Rp 2.400.000 dan farmer share 100 persen.

\section{KESIMPULAN DAN SARAN}

\section{Kesimpulan}

Dapat di simpulkan bahwa penelitian di Desa Matungkas dengan jumlah responden 39 orang yaitu: petani 24 orang, pedagang pengumpul 6 orang, dan pedagang pengecer 13 orang, dari 45 responden terdapat 3 pola saluran pemasaram di Desa Matungkas yaitu:

1. Pola Saluran pemasaran I sebesar $37,50 \%$ (petanipedagang pengupul-pedagang pengecerkonsumen)

2. Pola Saluran pemasaran II sebasar $54,16 \%$ (petani-pedagang pengecer di kabupaten/propinsikonsumen)

3. Salaran pemasaran II sebesar $3,34 \%$ (petanikonsumen)

Hasil penelitian menunjukan bahwa Marjin pemasaran pada saluran pertama sebesar Rp 8.640.000/trip dan farmer share sebesar 40,00 persen di pedagang penumpul dan saluran pemasaran kedua marjin pemasaran pada pedagang pengecer di kabupaten sebesar $\mathrm{Rp} 4.200 .000$ dan farmer share 58,82 persen sedangkan marjin pemasaran pada pedagang pengecer di propinsi sebesar $\mathrm{Rp}$ 
9.600.000/trip dan farmer share 50,00 persen. Marjin pada saluran pemasaran ketiga sebesar Rp 2.400.000 dan farmer share 100 persen.

Saluran pemasaran yang paling efisien adalah saluran pemasaran dua dan saluran pemasaran ketiga adalah saluran yang sangat menguntungkan bagi petani. Dimana saluran pemasaran kedua, marjin pemasaran $\mathrm{Rp}$ 4.200.000 dan farmer share 58,82 di pedagang pengecer dikabupaten dan pedagang pengecer di propinsi $\mathrm{Rp}$ 9.600.000/trip dan farmer share 50,00 persen dimana marjin pemasaran rendah dan farmer share tinggi. Pedagang pengecer mendatangi petani dan cara pemabayaran secara tunai,

Saluran pemasaran ketiga petani sendiri yang menjual buah pepaya ke konsumen dan resiko yang di tangung produsen yaitu pepaya busuk, tidak laku terjual di pasar dan persaingan serta permintaan penawaran pasar. Semakin lama buah pepaya di pasarkan maka semakin besar resiko yang di keluarkan. Marjin pemasaran sebesar $\mathrm{Rp} 2.400 .000$ dan farmer share 100 persen. Keuntungan yang di terima saluran pemasaran Rp 2.260.000.

\section{Saran}

Berdasarkan hasil penelitian, maka dapat direkomendasikan kepada petani pepaya di Desa Matungkas Kecamatan dimembe yang ingin meningkatkan keuntungannya sebaiknya memilih saluran pemasaran II dan III. Saluran pemasaran kedua petani tidak usah cape-cape menjual pepaya ke pasar karena pedagang pengecer yang mendatangi petani sedangkan saluran ketiga petani mendapat keuntungan yang lebih.

\section{DAFTAR PUSTAKA}

Ashari, S. 2004. Biologi Reproduksi Tanaman Buahbuhan Komersial. Malang: Penerbit: Banyumedia Publishing.

BPS (Badan Pusat Statistik) Propinsi Sulawesi Utara (2013-2014) Dalam Angka 2010-2015

BPS (Badan Pusat Statistik) Kabupaten Minahasa Utara (2013-2014) Dalam Angka 2013-2014.

Boyd et al. 2000 dalam Abednego. 2008. Manajemen Pemasaran; Suatu Pendekatan Stategis dengan Orientasi Global. Jakarta: Penerbit Erlangga.

Daiel, M. 2002. Pengantar Ekonomi Pertanian. Jakarta: Penerbit Sinar Gradika Offset

Direktorat Jendaral Hortikultura. 2015. Perkembangan PDB Komuditas Hortikultura Indonesia. http://hortikultura.deptan.go.id (diakses 29 januari 2016)

Haid, Abdul. 2006. Tataniaga Pertanian. Universitas Hasanuddin

Kelie, M. 2008. Bertanam Pepaya. Jakarta: Penerbit Penebar Swadaya

Kotler, Philip. 2009. Manajemen Pemasaran. Jakarta: Penerbit Erlangga.
Kotler dan Keler. 2007. Manajemen Pemasaran, Ed 12. Jilid2. Jakarta: Penerbit PT Indeks.

Laksana, Fajar.2008. Manajemen Pemasaran Yogyakarta: Penerbit Draha Ilmu.

Moehar. 2001. Pengantar Ekonomi Pertanian. Jakarta: Penerbit Bumi Aksara

Ningsi. 2011. Analalis Saluran Pemasaran dan Marjin Pemasaran Petani Jambu Air Camplong. Dosen Fakultaa Pertanian Universitas Islam Madura

Nitisemito, Alex. 2000. Manajemen Pemasaran. Jakaerta: Penerbit Ghalia Indonesia

Pandapotan. 2008. Analisis Pendapatan Usahatani dan Saluran Pemasaran pepaya California di Desa Cimande dan Desa Lemahduhur,Kecamatan Carigin. Skripsi Program Studi Manajemen Agribisisnis Fakultas Pertanian Institusi Pertanian Bogor. http://repository. ipb.ac.id/bitstream/123456789/1392/5/A08ap p.pdf (diakses 17 Februari 2016)

Pearce dan Robinson. (2011), Manajemen Strategis; formulasi, Implementasi, dan Pengendalian. Jakarta: Penerbit Salemba Empat

Rahim, A dan Hastuti. 2007. Ekonomi Pertanian. Jakarta: Penerbit Penebar Swadaya

Roziah. 2005. Studi Efisiensi Jalur Pemasaran Salak Pondoh di Kecamatan Turi Kabupaten Sleman. Skripsi Universitas Jendral Sudirman. Purwokorto.

Rukmana, R. 2003. Pepaya, Budidaya \& Pasca Panen. Yogyakarta: Penerbit Kanisius.

Sobirin, Tajus. 2009. Efisiensi Pemasaran Pepaya (Carica pepaya L.) di Kecamatan Sumbang. Skripsi Fakultas Pertanian Departemen Pendidikan Nasional Universitas Jendral Soedirman. https://www.scribd.com/doc/17716119/Skrips i-Sosial-Ekonomi-Pertanian-Tajus-SobirinA1C004047 (Diakses 18 februari 2016)

Sudiyono, A. 2002. Pemasaran Pertanian. Malang: Penerbit UMM Press Malang

Sunarjono, H. Hendro. 2015. Bertanam 36 jenis sayur.Depok: Penerbit Swadaya.

Suratiyah. 2006. Ilmu Usahatani. Jakarata: Penerbit Penebar Swadaya.

Susilo, H. 2006. Efisiensi Pemasaran Melon Di Kabupaten Klaten. Skripsi Program Studi Sosial Ekonomi Pertanian/Agrobisnis Fakultas Pertanian. Universitas Sebelas Maret Surakarta.

Swasta, B dan Handoko, H. 2010. Manajemen Pemasaran; Analisa dan Perilaku Konsumen.Yogyakarta: Penerbit BPFE

Usman. 2006. Manajemen Pemasaran. Yogyakarta: Penerbit Amara Books.

Widiastuti, N. 2013. Saluran Pemasaran dan Marjin Pemasaran Jagung di Kabupaten Grobongan. Program studi Agribisnis Fakultas Petanian Universitas Sebelah Maret Surakarta. 